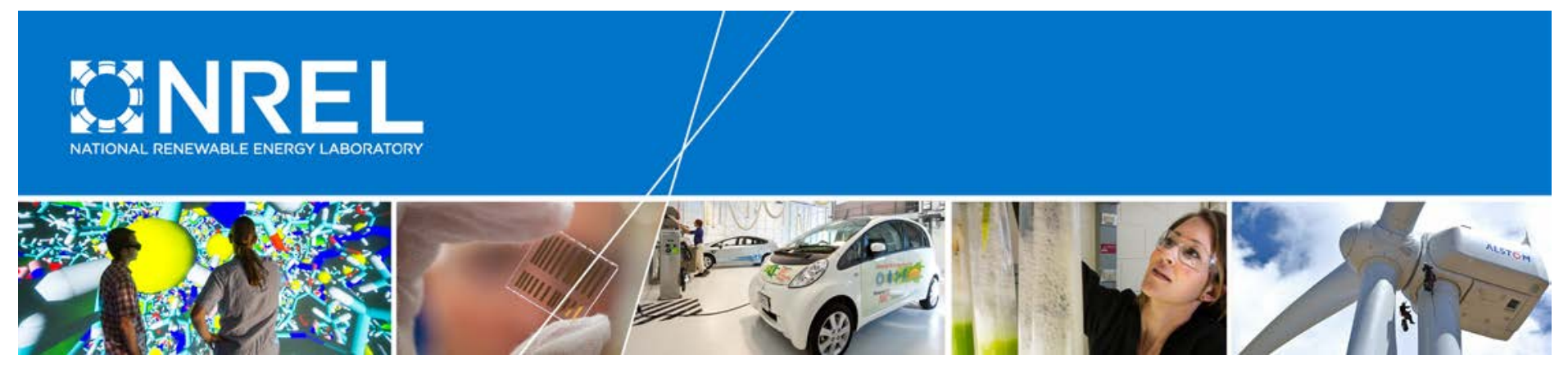

\title{
Comparison of Standards and Technical Requirements of Grid- Connected Wind Power Plants in China and the United States
}

David Wenzhong Gao Alternative Power Innovations, LLC

Eduard Muljadi, Tian Tian, and Mackay Miller National Renewable Energy Laboratory

Weisheng Wang China Electric Power Research Institute

NREL is a national laboratory of the U.S. Department of Energy Office of Energy Efficiency \& Renewable Energy Operated by the Alliance for Sustainable Energy, LLC

This report is available at no cost from the National Renewable Energy Laboratory (NREL) at www.nrel.gov/publications.

Technical Report

NREL/TP-5D00-64225

September 2016

Contract No. DE-AC36-08G028308 


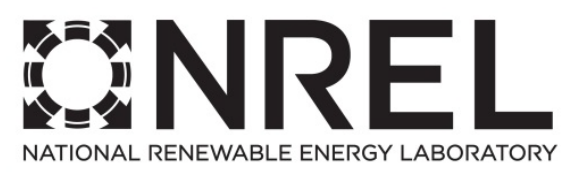

\section{Comparison of Standards and Technical Requirements of Grid- Connected Wind Power Plants in China and the United States}

David Wenzhong Gao

Alternative Power Innovations, LLC

Eduard Muljadi, Tian Tian, and Mackay Miller National Renewable Energy Laboratory

Weisheng Wang

China Electric Power Research Institute

Prepared under Task Nos. IGIN.1840 and IGIN.1850

NREL is a national laboratory of the U.S. Department of Energy Office of Energy Efficiency \& Renewable Energy Operated by the Alliance for Sustainable Energy, LLC

This report is available at no cost from the National Renewable Energy Laboratory (NREL) at www.nrel.gov/publications.

National Renewable Energy Laboratory 15013 Denver West Parkway Golden, CO 80401

303-275-3000 • www.nrel.gov
Technical Report

NREL/TP-5D00-64225

September 2016

Contract No. DE-AC36-08GO28308 


\section{NOTICE}

This report was prepared as an account of work sponsored by an agency of the United States government. Neither the United States government nor any agency thereof, nor any of their employees, makes any warranty, express or implied, or assumes any legal liability or responsibility for the accuracy, completeness, or usefulness of any information, apparatus, product, or process disclosed, or represents that its use would not infringe privately owned rights. Reference herein to any specific commercial product, process, or service by trade name, trademark, manufacturer, or otherwise does not necessarily constitute or imply its endorsement, recommendation, or favoring by the United States government or any agency thereof. The views and opinions of authors expressed herein do not necessarily state or reflect those of the United States government or any agency thereof.

This report is available at no cost from the National Renewable Energy Laboratory (NREL) at www.nrel.gov/publications.

Available electronically at SciTech Connect http:/www.osti.gov/scitech

Available for a processing fee to U.S. Department of Energy and its contractors, in paper, from:

U.S. Department of Energy

Office of Scientific and Technical Information

P.O. Box 62

Oak Ridge, TN 37831-0062

OSTI http://www.osti.gov

Phone: 865.576.8401

Fax: 865.576.5728

Email: reports@osti.gov

Available for sale to the public, in paper, from:

U.S. Department of Commerce

National Technical Information Service

5301 Shawnee Road

Alexandria, VA 22312

NTIS http://www.ntis.gov

Phone: 800.553 .6847 or 703.605 .6000

Fax: 703.605.6900

Email: orders@ntis.gov 


\section{Acknowledgments}

This report was funded under the international team of the U.S.- China Renewable Energy Partnership through the U.S. Department of Energy's Office of Energy Efficiency and Renewable Energy's international team. The authors would like to thank the U.S. China Renewable Energy Partnership team for the opportunity to collaborate on the scoping and development of this study. For their review and comments, the authors would like to thank Sandip Sharma from the Electric Reliability Council of Texas; Yong Cheol Kang from Chonbuk National University, Korea; Nirmal-Kumar C. Nair from the University of Auckland, New Zealand; and Arlene Fetizanan from the U.S. Department of Energy. The authors also thank Katie Wensuc of the National Renewable Energy Laboratory for editorial review and support. Any errors or omissions are solely the responsibility of the authors. 


\section{List of Acronyms}

ERCOT

FERC

GW

HVRT

$\mathrm{Hz}$

IEEE

ISO-NE

IVGTF

$\mathrm{kV}$

LGIA

LVRT

ms

MVA

MW

NERC

PCC

POI

SCADA

VAR

WPP

WTG
Electric Reliability Council of Texas

Federal Energy Regulatory Commission

gigawatt

high-voltage ride-through

hertz

Institute of Electrical and Electronics Engineers

Independent System Operator-New England

Integration of Variable Generation Task Force

kilovolt

Large Generator Interconnection Agreement

low-voltage ride-through

millisecond

megavolt-ampere

megawatt

North American Electric Reliability Corporation point of common coupling

point of interconnection

supervisory control and data acquisition

volt-ampere reactive

wind power plant

wind turbine generator 


\section{Executive Summary}

The rapid deployment of wind power has made grid integration and operational issues focal points in industry discussions and research. Compliance with grid connection standards for wind power plants (WPPs) is crucial to ensuring the reliable and stable operation of the electric power grid. This report compares the standards for grid-connected WPPs in China to those in the United States to facilitate further improvements in wind power standards and enhance the development of wind power equipment. Detailed analyses of power quality, low-voltage ride-through capability, active power control, reactive power control, voltage control, and wind power forecasting are provided to enhance the understanding of grid codes in the world's two largest markets of wind power.

This study compares WPP interconnection standards and technical requirements in China to those in the United States. The major goals of this report are to:

- Understand the current status of WPP interconnection standards in China and the United States to provide a good reference for the development and enhancement of the framework of related wind power standards in both countries

- Analyze and compare typical utility connection requirements for WPPs to provide a good reference for the development and enhancement of WPP interconnection requirements in both countries

- Understand the specific and unique technical requirements for WPPs in China to be able to make relevant recommendations to related standards development organizations at the international level. 


\section{Table of Contents}

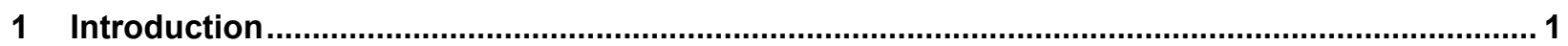

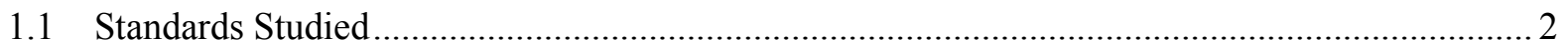

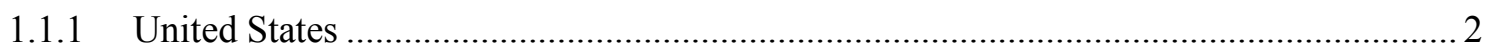

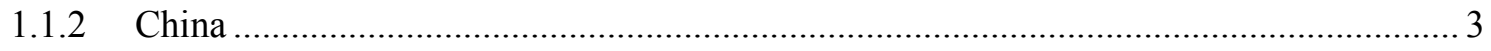

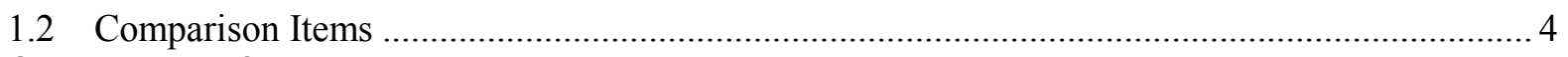

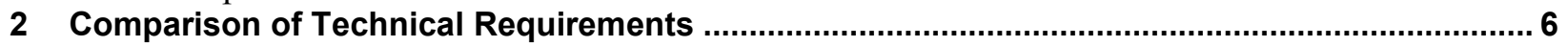

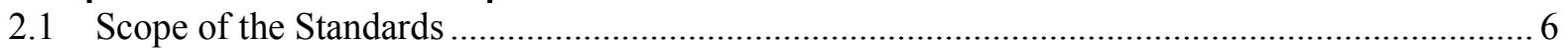

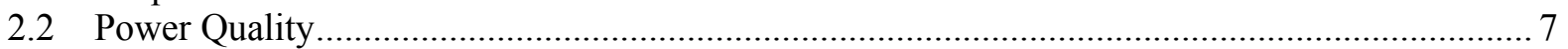

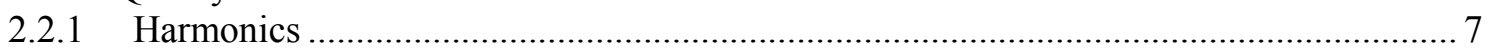

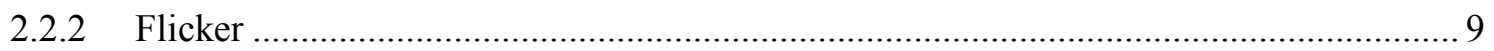

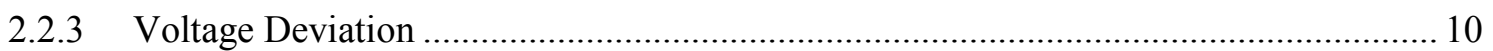

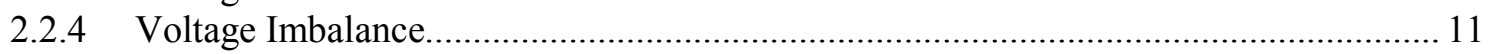

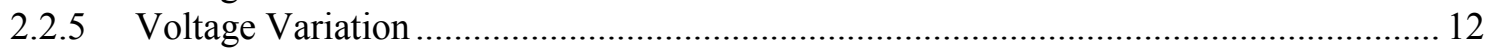

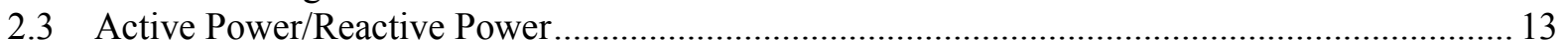

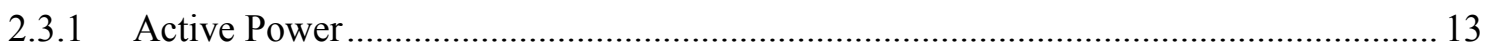

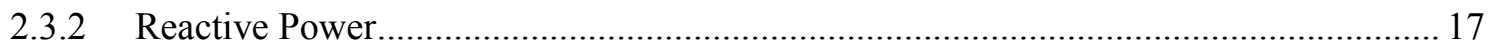

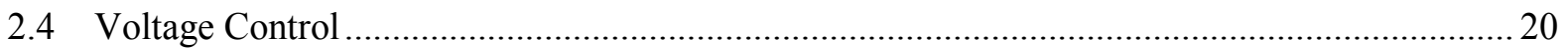

2.5 Active Power Feed-In at Overfrequency/Underfrequency .............................................. 23

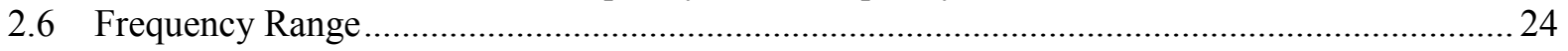

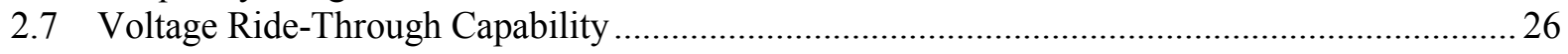

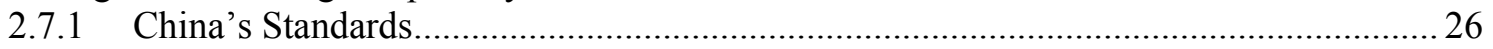

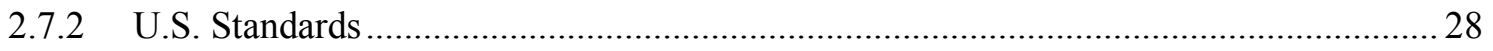

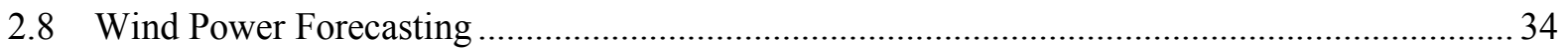

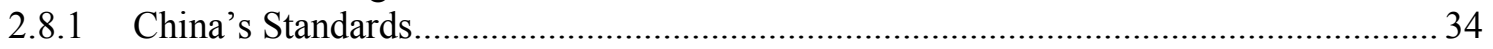

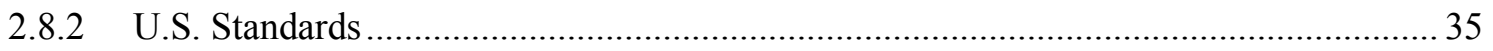

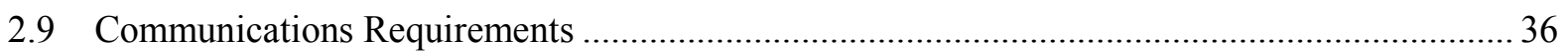

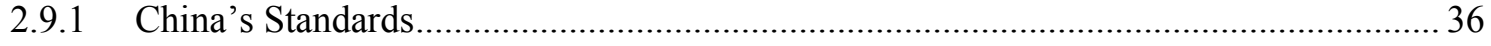

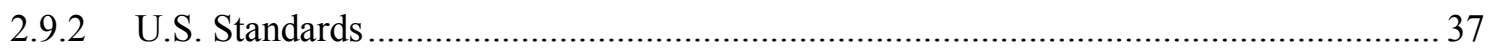

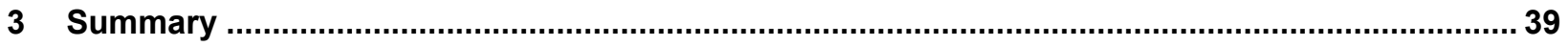

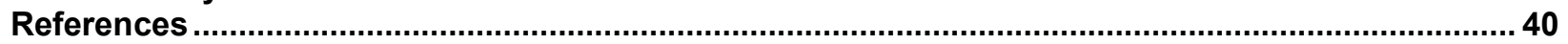




\section{List of Figures}

Figure 1. Off-nominal frequency capability curve under NERC generator frequency and voltage

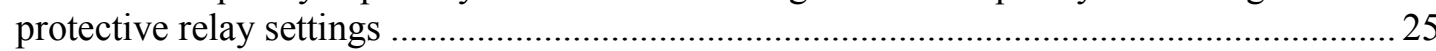

Figure 2. LVRT requirements for WPP interconnection in China (GB/T 19963) ...............................22

Figure 3. LVRT requirements in the United States (FERC Order No. 661) ...........................................29

Figure 4. Voltage ride-through time duration curve (NERC PRC-024-1) ............................................. 31

Figure 5. Default voltage ride-through boundaries for intermittent renewable resources in ERCOT

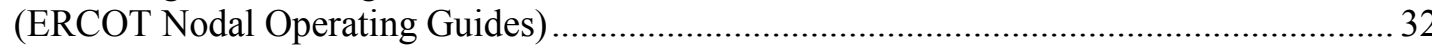

Figure 6. Comparison of LVRT requirements in China to those in the United States.............................. 33

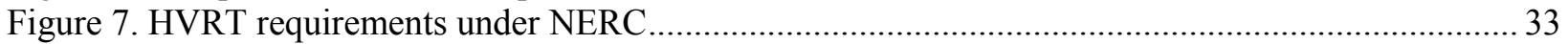




\section{List of Tables}

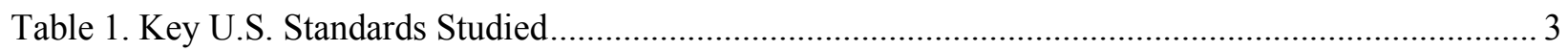

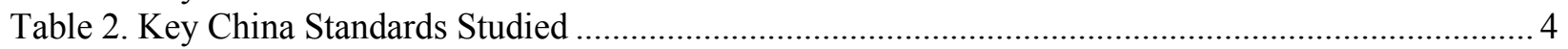

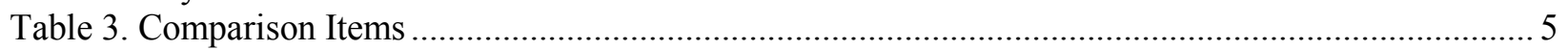

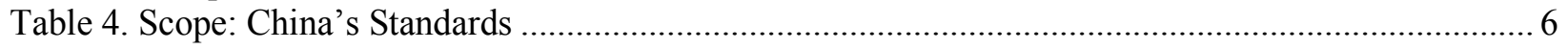

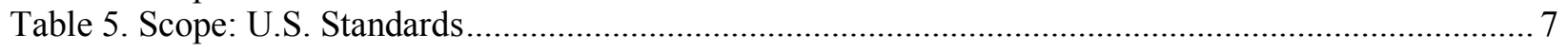

Table 6. Summary of the Comparison of the Scope of the Standards ….................................................. 7

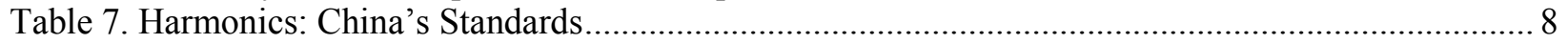

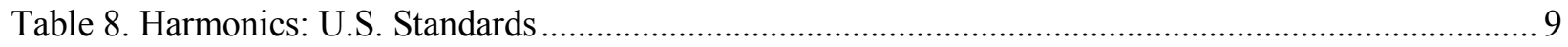

Table 9. Summary of the Comparison of the Standards for Harmonics ................................................... 9

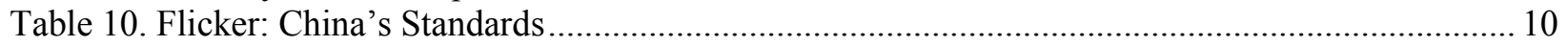

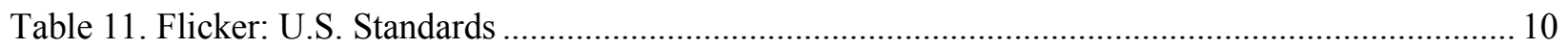

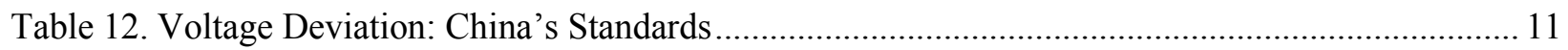

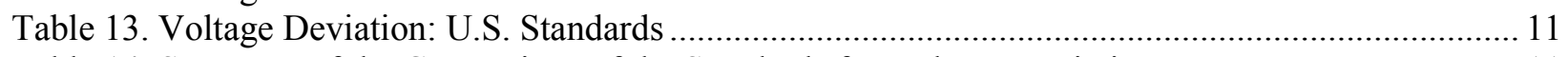

Table 14. Summary of the Comparison of the Standards for Voltage Deviation ..................................... 11

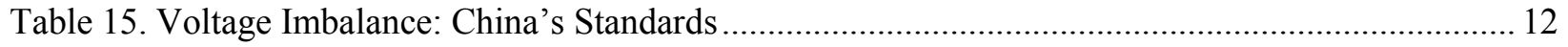

Table 16. Summary of the Comparison of the Standards for Voltage Imbalance ..................................... 12

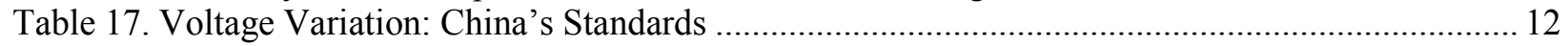

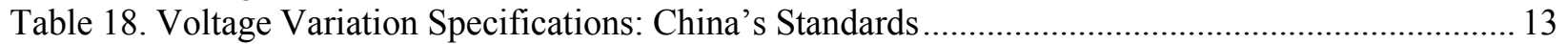

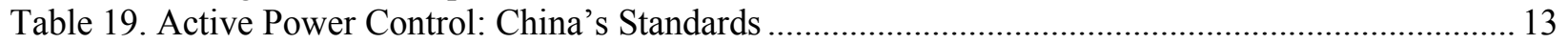

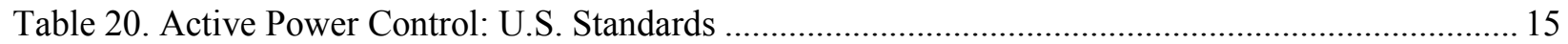

Table 21. Summary of the Comparison of the Standards for Active Power Control................................. 17

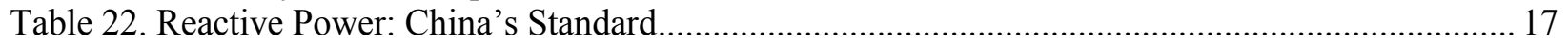

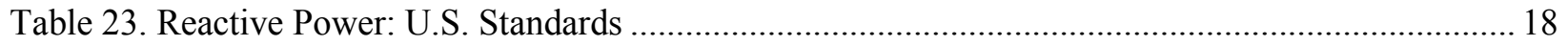

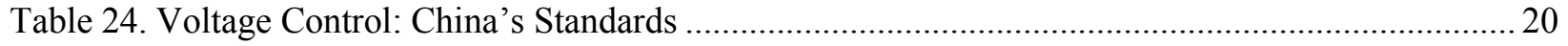

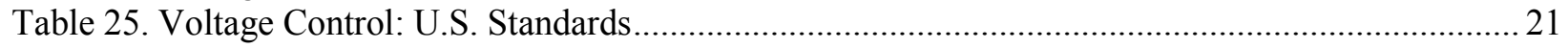

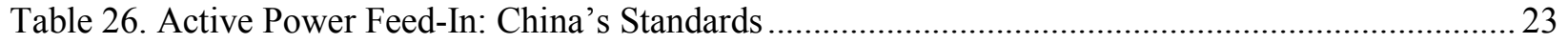

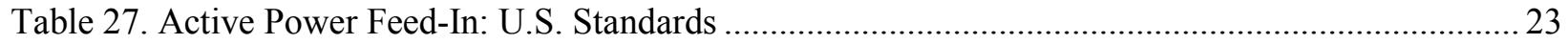

Table 28. Summary of the Comparison of the Standards for Active Power Feed-In ............................... 24

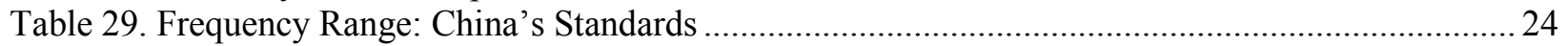

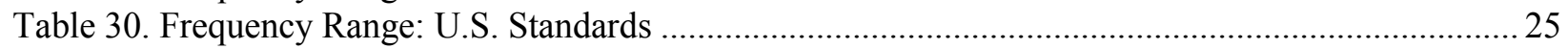

Table 31. ERCOT's Operating Guides 2.6.2 Underfrequency and Overfrequency Requirements.............26

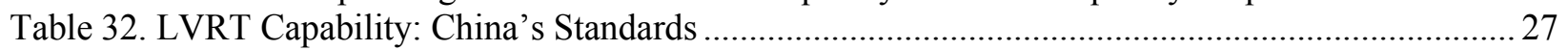

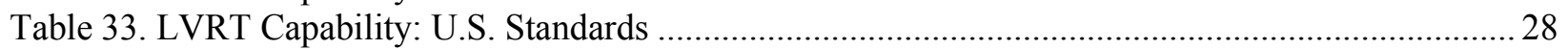

Table 34. Comparative Summary of Standards for Voltage Ride-through Capability ............................. 33

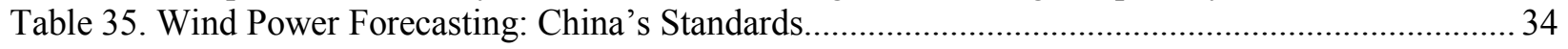

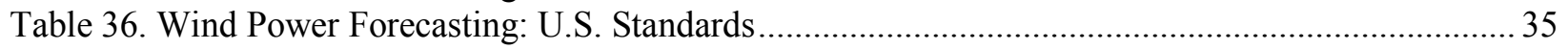

Table 37. Summary of the Comparison of the Wind Power Forecasting Standards.................................. 36

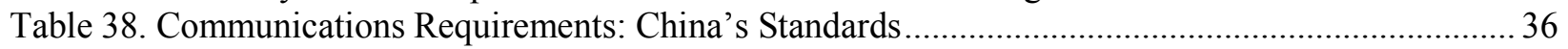

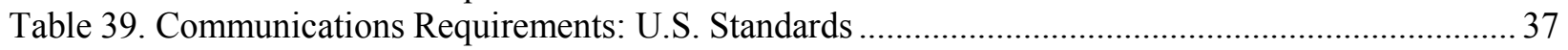

Table 40. Summary of the Comparison of the Standards for the Communications Requirements ............ 38 


\section{Introduction}

Wind energy has experienced significant growth, accumulating 369,597 GW of global installed capacity at the end of 2014 [1]. In the United States, wind energy installations totaled more than $61 \mathrm{GW}$ at the end of 2014 , contributing $4.4 \%$ of the country's total electricity generation [2]. China has become one of the fastest growing markets for wind power. At the end of 2014, China had connected $96.37 \mathrm{GW}$ of wind power to the grid, which accounted for $7 \%$ of the total installed capacity [3]. Both China and the United States have developed robust wind generation markets coupled with ambitious targets that point to scenarios of high penetrations of wind power in the future.

In both countries, the rapid deployment of wind power has posed new challenges in maintaining grid stability and reliability in large-scale electric power system operations. China, in particular, has suffered severe integration issues because technical standards for wind power plants (WPPs) lagged behind the surge in installations. The lack of appropriate standardization caused many WPP developers in the industry to maximize the power rating using inexpensive technology without concern for power quality [4]. Lacking low-voltage ride-through (LVRT) capability, many wind turbines disconnected from the grid during voltage dips [5]. Low-quality power generated from wind was exacerbated by weak grids in high-wind regions in the western and northern parts of China as well as the massive interconnection of WPPs from the major wind bases [6]. These factors, along with a number of other technical and policy challenges, contributed to low utilization rates of wind power in China - wind curtailment rates reached $17.1 \%$ in 2012 , recording only 1,890 hours of utilization [7]. In 2011, the Chinese government issued a mandate for WPPs and turbines to meet a set of interconnection standards, enforcing national compliance for the first time [8]. To increase the amount of wind energy generation and enhance grid performance, China has plans to continuously update and optimize its grid code in accordance with the penetration level and strength of the regional power networks.

The United States experienced similar challenges as wind power reached commercial viability. As wind turbine installations moved beyond the relatively strong portion of the network in Northern California, many plants experienced voltage problems due to inadequate reactive power supply in a relatively weak transmission network [9]. The majority of the commercial wind developments in high-wind resource areas were interconnected to relatively weak portions of the bulk power systems in Texas and the upper Great Plains, away from load centers. Since the early 2000s, grid codes have evolved under different jurisdictions in the United States, helping to define WPP interconnection specifications within the bulk power system and drive improvements in wind turbine system design, particularly for control and electric power systems [9].

This report compares standards and technical requirements for grid-connected WPPs in China to those in the United States. The main objectives are to:

- Understand the current status of WPP interconnection standards in China and the United States to provide reference for the development and enhancement of the wind power standardization framework in both countries

- Analyze and compare utility connection requirements for power quality, LVRT capability, active and reactive power control, voltage control, and wind power forecasting 
to define and lower the technical barriers for wind turbine equipment suppliers to both countries

- Understand the specific and unique characteristics of China's technical requirements for WPPs to make recommendations to relevant standards development organizations at the international level.

This study focuses on requirements for large-scale wind power generation and interconnection in the bulk power system. Note that wind power systems that are considered "distributed generation" (less than $20 \mathrm{MW}$ ) merit additional research and are not covered here. Further, the report heavily relies on the original standards, rules, and regulations that are listed in the references section. In many cases, information is directly taken from relevant original sources of these standards for the purpose of comparative analysis.

\subsection{Standards Studied}

To ensure that wind turbine generators (WTGs) behave more like conventional power plants with synchronous generators, transmission system operators in various countries have designed technical standards for WPPs. These interconnection standards require WPPs to contribute to power system (voltage and frequency) control and define turbine behavior during grid disturbances [10]. In addition to maintaining transmission stability, wind grid codes also increase the transparency of technical negotiations between the power plant and transmission system operators and outline the technical parameters for wind power equipment providers [11].

\subsubsection{United States}

The surge in variable generation from wind prompted the development of formal technical interconnection procedures and standards for wind power systems in the United States [9]. The U.S. Federal Energy Regulatory Commission's ' ${ }^{1}$ (FERC)'s 2003 order (FERC Order No. 2003) proposed a "Large Generator Interconnection Procedure" and a "Large Generator Interconnection Agreement" (LGIA) for all generators with a generation capacity greater than 20 MW, but it made no distinction between synchronous and variable-speed generators [9]. In response, the wind industry, including the American Wind Energy Association and the Western Electricity Coordinating Council, developed proposals for interconnection standards and guidelines specific to wind generation [9]. In June 2005, FERC issued Order No. 661, requiring public utilities to include technical requirements and standard procedures for the interconnection of large wind-generating plants in their large generator interconnection procedures and LGIAs [12]. The requirements address LVRT capability, supervisory control and data acquisition (SCADA) capability, and power factor design criteria. After the American Wind Energy Association and the North American Electric Reliability Corporation (NERC) ${ }^{2}$ jointly proposed changes to the LVRT standard, FERC issued Order No. 661-A in December 2005, updating the LVRT provision in Order No. 661 [13].

\footnotetext{
${ }^{1}$ FERC, a U.S. federal agency, has jurisdiction over interstate electricity sales, wholesale electric rates, and other energy matters.

${ }^{2}$ NERC, a nonprofit regulatory authority, ensures electric reliability in North America under the oversight of FERC and government authorities in Canada. NERC develops and enforces reliability standards and has jurisdiction over users, owners, and operators of the bulk electric power system.
} 
In 2012, NERC's Integration of Variable Generation Task Force (IVGTF) ${ }^{3}$ released a special assessment of its "Interconnection Requirements for Variable Generation" to address voltage and frequency ride-through, reactive and real power control, and frequency/inertial response criteria specific to the technical characteristics of variable generation [14]. Recommendations from IVGTF to update standards and procedures are currently being implemented.

In compliance with NERC and FERC standards, regional reliability organizations have established regional versions of the grid codes. The two regional grid codes studied here are from the Independent System Operator-New England (ISO-NE) and the Electric Reliability Council of Texas (ERCOT). These two regional grid codes were studied because both have relatively high wind installation targets, designed their grid codes after extensive studies, and are representative of subnational grid codes. In November 2009, ISO-NE released the "Technical Requirements for Wind Generation Interconnection and Integration" as part of its wind integration study, commissioned "in anticipation of significant wind generation development" [15]. Prepared by GE, EnerNex, and AWS Trupower, the study makes specific recommendations for ISO-NE's wind interconnection policies and practices. ERCOT has incorporated many technical requirements for WPPs into its "Nodal Operating Guides," which specifies practices for the ERCOT system in congruence with NERC standards and ERCOT "Nodal Protocols." In July 2010, ERCOT released a summary of the significant WPP requirements in its region that specified the three requirements placed on WTGs in ERCOT "above and beyond their general responsibilities as interconnected generators": voltage ride-through, reactive support, and frequency response [16].

Table 1. Key U.S. Standards Studied

\begin{tabular}{lllc}
\hline No. & Standard & Title & Version \\
\hline 1 & FERC Order No. 661/661A & Interconnection for Wind Energy & 2005 \\
2 & NERC & $\begin{array}{l}2012 \text { Special Assessment: Interconnection Requirements for } \\
\text { Variable Generation } \\
\text { "Summary of Significant Wind Power Plant Requirements in }\end{array}$ & 2012 \\
3 & ERCOT & $\begin{array}{l}\text { ERCOT"; ERCOT Nodal Operating Guides; Generation } \\
\text { Interconnection or Change Request Procedure }\end{array}$ & 2010 \\
4 & ISO-NE & $\begin{array}{l}\text { Technical Requirements for Wind Generation Interconnection } \\
\text { and Integration; ISO-NE Large Generator Interconnection }\end{array}$ & 2009 \\
\hline
\end{tabular}

\subsubsection{China}

Wind integration challenges in China's bulk power system called for integration standards. In 2005, the China Electric Power Research Institute led the development of the "Technical Rules for Connecting Wind Farm to Power Systems," GB/Z 19963-2005 [17]. The rules were published at the beginning of China's wind power industry in the early to mid-2000s and were considered recommendations rather than compulsory standards. These were later replaced by GB/T 19963-2011 as the industry matured [18].

\footnotetext{
${ }^{3}$ For more information on IVGTF, see http://www.nerc.com/comm/PC/Pages/Integration-of-Variable-GenerationTask-Force-(IVGTF)-2013.aspx.
} 
In December 2009, China's State Grid Corporation issued the enterprise standard "Technical Rule for Connecting Wind Farm Into Power Grid," Q/GDW 392-2009 [19], which established that WPPs should have power control, wind power forecasting, LVRT, and communications capabilities to be compatible with China's electric power grid system. Nevertheless, without official guidance from the government, these standards were not enforceable nationally.

In August 2011, the National Energy Administration issued the industry standard on the "Wind Power Interconnection Technical Regulations," NB/T 31003-2011, which specified the design of technical requirements for large-scale WPP connection [20].

Finally, in December 2011, the General Administration of Quality Supervision Inspection and Quarantine and the Standard Administration of China issued the "Technical Rule for Connecting Wind Farm to Power System," GB/T 19963-2011, establishing national compulsory interconnection requirements; these were implemented in June 2012 [8]. Much of the content of the State Grid enterprise standard, Q/GDW 392-2009, has been updated and incorporated into the new national standard, GB/T 19963-2011 ${ }^{4}$; thus, the enterprise standard is referenced in this study, but it is not analyzed in the comparative sections.

Table 2. Key China Standards Studied

\begin{tabular}{lllc}
\hline No. & Standard & Title & Version \\
\hline \multirow{2}{*}{$\begin{array}{l}\text { Standard Administration of China: } \\
\text { GB/T 19963-2005 and } \\
\text { GB/Z 19963-2011 }\end{array}$} & $\begin{array}{l}\text { Technical Rule for Connecting Wind Farm to } \\
\text { Power System }\end{array}$ & 2011 \\
2 & $\begin{array}{l}\text { National Energy Administration: NB/T } \\
\text { 31003-2011 }\end{array}$ & $\begin{array}{l}\text { Wind Power Interconnection Technical } \\
\text { Regulations }\end{array}$ & 2011 \\
3 & State Grid Corporation: & $\begin{array}{l}\text { Technical Rule for Connecting Wind Farm Into } \\
\text { Q/GDW 392-2009 }\end{array}$ & 2009 \\
\hline
\end{tabular}

\subsection{Comparison Items}

The comparison of the WPP interconnection standards in this paper focuses on the scope and application range of these standards along with nine technical aspects, as listed in Table 3.

${ }^{4}$ The passage of the mandatory GB/T 19963-2011 in China replaced the voluntary GB/Z 19963-2005. 
Table 3. Comparison Items

\begin{tabular}{ll}
\hline No. & Comparison Items \\
\hline 1 & Scope of the standards \\
Power quality \\
A. Harmonics \\
B. Flicker \\
C. Voltage deviation \\
D. Voltage imbalance \\
E. Voltage variation
\end{tabular}




\section{Comparison of Technical Requirements}

\subsection{Scope of the Standards}

This section compares the application ranges of the standards. Table 4 through Table 6 compare the scopes of the standards.

This comparative study includes three levels of WPP interconnection standards in China: (1) the national standard (GB/T 19963-2011), (2) the industry standard set by China's National Energy Administration (NB/T 31003-2011), and (3) the enterprise standard established by the State Grid Corporation of China (Q/GDW 392-2009). The national standard and the enterprise standard classify WPPs by their voltage level, whereas the industry standard classifies WPPs by their voltage level and the installed capacity. GB/T 19963 and Q/GDW 392-2009 are applicable to any newly constructed or extended WPPs connected to a power system through a line with a voltage level of 110 (66) kV or higher. When NB/T 31003-2011 was enacted, it was intended for new WPPs or WPP group projects with a capacity of $200 \mathrm{MW}$ or more.

The key U.S. wind interconnection standards analyzed include (1) FERC Order No. 661/661A, (2) NERC's “Interconnection Requirements for Variable Generation," (3) ERCOT's wind interconnection standards, and (4) ISO-NE's interconnection standards. FERC Order No. $661 / 661 \mathrm{~A}$ is applicable to the interconnection of new wind facilities with capacities more than 20 MW. ERCOT and ISO-NE standards generally apply to wind facilities in the bulk power system $(>20 \mathrm{MW})$.

Table 4. Scope: China's Standards

\begin{tabular}{|c|c|c|}
\hline Standard & Section & Scope \\
\hline \multirow{2}{*}{ GB/T 19963-2011 } & \multirow{2}{*}{1} & $\begin{array}{l}\text { This standard applies to newly constructed or expanded WPPs that are } \\
\text { connected to the grid through a voltage level of } 110(66) \mathrm{kV} \text { or higher. }\end{array}$ \\
\hline & & $\begin{array}{l}\text { This standard can be used as a reference for WPPs connected to a power } \\
\text { system through other voltage levels. }\end{array}$ \\
\hline \multirow{3}{*}{ NB/T 31003-2011 } & \multirow{3}{*}{1.0 .2} & This standard applies to: \\
\hline & & $\begin{array}{l}\text { 1. New WPPs or groups of WPPs with a planned capacity of } 200 \\
\text { MW or more }\end{array}$ \\
\hline & & $\begin{array}{l}\text { 2. Newly constructed or expanded WPPs that are connected directly } \\
\text { (or after a collector station) to the grid at a voltage level of } 220 \mathrm{kV} \\
\text { or higher. }\end{array}$ \\
\hline \multirow{2}{*}{ Q/GDW 392-2009 } & \multirow{2}{*}{1} & $\begin{array}{l}\text { This standard applies to newly constructed or expanded WPPs connected } \\
\text { to the grid through a voltage level of } 110(66) \mathrm{kV} \text { or higher. }\end{array}$ \\
\hline & & $\begin{array}{l}\text { This standard can be a reference for WPPs connected to a power system } \\
\text { through other voltage levels. }\end{array}$ \\
\hline
\end{tabular}


Table 5. Scope: U.S. Standards

\begin{tabular}{|c|c|c|}
\hline Standard & Section & Scope \\
\hline FERC Order No. 661/661A & & $\begin{array}{l}\text { This standard applies to the interconnection of new } \\
\text { wind facilities with a capacity more than } 20 \mathrm{MW} \text {. }\end{array}$ \\
\hline NERC Recommendation & & $\begin{array}{l}\text { These regulations apply to the bulk electric system within NERC } \\
\text { jurisdiction. }\end{array}$ \\
\hline ERCOT & & $\begin{array}{l}\text { ERCOT's voltage control requirements apply to generating } \\
\text { facilities with a capacity more than } 20 \text { megavolt-amperes } \\
\text { (MVA), and active control is required for all generating } \\
\text { resources. }\end{array}$ \\
\hline ISO-NE & & $\begin{array}{l}\text { These standards generally apply to the bulk power systems } \\
\text { within the ISO-NE service region (> } 20 \mathrm{MW}) \text {. }\end{array}$ \\
\hline
\end{tabular}

Table 6. Summary of the Comparison of the Scope of the Standards

\begin{tabular}{lll}
\hline & China's Standards & U.S. Standards \\
\hline GB/T 19963-2011: >110 (66) kV & NERC standards: $\geq 100 \mathrm{kV}$ \\
According to voltage level & NB/T 31003-2011: $\geq 220 \mathrm{kV}$ & $\begin{array}{l}\text { Regional reliability organization } \\
\text { Q/GDW 392-2009: >110 (66) kV }\end{array}$ \\
& & FERC Order No. 661: > 20 MW \\
According to installed capacity & NB/T 31003-2011: $\geq 200 \mathrm{MW}$ & FERC Order No. 661A: $>20 \mathrm{MW}$ \\
\hline
\end{tabular}

As noted above, because most of the contents of Q/GDW 392-2009 were updated and incorporated into the newly issued national standard GB/T 19963-2011, it was not included or compared further in this study.

\subsection{Power Quality}

A comparison of the requirements for harmonics; flicker; and voltage deviation, imbalance, and variation helps determine the differences between standards in the United States and China for the power quality of grid-connected WPPs.

\subsubsection{Harmonics}

China's standards for harmonic requirements comply with GB/T 14549, "Quality of Electric Energy Supply Harmonics in Public Supply Network." This standard defines the tolerable value of harmonics in the public grid and the measurement method for harmonics. It is suitable for the alternating-current, public, electric power grid with a rated frequency of $50 \mathrm{~Hz}$ and rated voltage less than $110 \mathrm{kV}$. It defines the limitation of harmonic voltage and the allowable value of harmonic current under different standard voltages (including $0.38 \mathrm{kV}, 6 \mathrm{kV}, 10 \mathrm{kV}, 35 \mathrm{kV}, 66$ $\mathrm{kV}$, and $110 \mathrm{kV}$ ). The permissible harmonic current injected into the power system by a WPP should be distributed according to the ratio of the installed capacity of the WPP to the total capacity of the generating/supply equipment with the harmonic source at the point of interconnection (POI). 
U.S. requirements for harmonics mostly follow the Institute of Electrical and Electronics Engineers (IEEE) Standard 519, "Recommended Practice and Requirements for Harmonic Control in Electric Power Systems." Although FERC Order No. 661 does not specifically address harmonics, FERC's LGIA (Section 9.7.6.) stipulates that the facilities should not cause "excessive voltage flicker nor introduce excessive distortion" to the voltage or current waves in accordance with IEEE Standard 519 and other relevant electricity industry standards [21]. ISO-NE's "Technical Requirements for Wind Generation Interconnection and Integration" specifically recommends that harmonics requirements for WPPs should comply with IEEE 519. On a turbine-by-turbine basis, the requirement limits the total harmonic distortion of the current at the terminals of the machine to less than or equal to $5 \%$ of the rated fundamental frequency (from $1 \mathrm{kV}-69 \mathrm{kV})^{5}[15]$. According to IEEE 519, the current distortion limits are determined by the short-circuit ratio, or the ratio of short-circuit current at the point of common coupling (PCC) to the maximum load or demand current.

Table 7. Harmonics: China's Standards

\begin{tabular}{|c|c|c|}
\hline Standard & Sec. & Requirement \\
\hline GB/T 19963 & 11.3 & $\begin{array}{l}\text { The harmonic current injection at the POI should meet the requirements of } \\
\text { GB/T } 14549 .{ }^{6} \text { The permissible harmonic currents injected into the power } \\
\text { system by the WPP shall be distributed according to the ratio of the installed } \\
\text { capacity of the concerned WPP to the total capacity of the generating/supply } \\
\text { equipment containing harmonic sources at the POI. }\end{array}$ \\
\hline NB/T 31003-2011 & 5.4 & $\begin{array}{l}\text { The harmonic current injection at a WPP's POI should meet GB/T } 14549 \\
\text { specifications. The permissible harmonic currents injected into the power } \\
\text { system by the WPP shall be distributed according to the ratio of the installed } \\
\text { capacity of the concerned WPP to the total capacity of the generating/supply } \\
\text { equipment containing harmonic sources at the POI. }\end{array}$ \\
\hline
\end{tabular}

\footnotetext{
${ }^{5}$ At higher voltages (from $69 \mathrm{kV}-161 \mathrm{kV}$ ), the total harmonic distortion is limited to $2.5 \%$.

${ }^{6}$ GB/T 14549 "Quality of Electric Energy Supply Harmonics in Public Supply Network"
} 
Table 8. Harmonics: U.S. Standards

\begin{tabular}{|c|c|c|}
\hline Standard & Sec. & Requirement \\
\hline FERC Order No. 661/661A & & No \\
\hline FERC LGIA & 9.7 .6 & Compliance with IEEE 519 \\
\hline \multirow{4}{*}{$\begin{array}{l}\text { NERC } \\
\text { Interconnection } \\
\text { Requirements for Variable } \\
\text { Generation (2012) }\end{array}$} & & $\begin{array}{l}\text { IVGTF recommendation: There is no need for NERC to develop } \\
\text { additional interconnection criteria for subsynchronous } \\
\text { resonance/subsynchronous interactions or harmonics; however, }\end{array}$ \\
\hline & & $\begin{array}{l}\text { - Synchronization of generators to the grid should not cause } \\
\text { excessive dynamic or steady-state voltage changes at the POI; } \\
\text { a } 2 \% \text { limit may be considered as a baseline. }\end{array}$ \\
\hline & & $\begin{array}{l}\text { - Design studies that assess the harmonic performance of all } \\
\text { wind and solar plants }\end{array}$ \\
\hline & & $\begin{array}{l}\text { - Technical guideline document to understand the control } \\
\text { interactions and assess and mitigate the risks of wind and solar } \\
\text { power plants located near series-compensated transmission } \\
\text { lines. }\end{array}$ \\
\hline $\begin{array}{l}\text { ERCOT Interconnection or } \\
\text { Change Request Procedure } \\
(2004)\end{array}$ & & Compliance with IEEE 519 \\
\hline ISO-NE & & \multirow[b]{2}{*}{$\begin{array}{l}\text { Compliance with IEEE } 519 \text { in interconnection requirements.stablish } \\
\text { guidance (same as that provided to all generation and industrial } \\
\text { interconnections) regarding background distortion on the network } \\
\text { in plant design and substation modifications. }\end{array}$} \\
\hline $\begin{array}{l}\text { Technical Requirements for } \\
\text { Wind Generation } \\
\text { Interconnection and } \\
\text { Integration }\end{array}$ & 3.5 & \\
\hline
\end{tabular}

Table 9. Summary of the Comparison of the Standards for Harmonics

\begin{tabular}{lll}
\hline & China's Standards & U.S. Standards \\
\hline $\begin{array}{l}\text { Harmonic current } \\
\text { measurement }\end{array}$ & Requirements specified & Requirements specified \\
Interharmonics & No requirements & No requirements \\
$\begin{array}{l}\text { Calculation method } \\
\begin{array}{l}\text { Maximum harmonic order } \\
\text { measured }\end{array}\end{array}$ & Above $25^{\text {th }}$ order & $\begin{array}{l}\text { One-time calculation, at rated output, } \\
\text { during commissioning }\end{array}$ \\
\hline
\end{tabular}

\subsubsection{Flicker}

China's standards (with reference to GB/T 12326, "Power Quality_Voltage Fluctuation and Flicker") have definite quantitative flicker requirements. The interference value for flicker at the POI of a WPP should meet the requirements of GB/T 12326. The limit of the long-term flicker value, $\mathrm{P}_{1 \mathrm{t}}$ (calculated for a 2-hour time frame), caused by the WPP shall be assigned according to the ratio of the installed capacity of the WPP to the total capacity of the interference source at the PCC. In GE Energy's study of ISO-NE on the Technical Requirements for Wind Generation Interconnection and Integration, the test for the voltage flicker index is based on the short-term flicker value, $\mathrm{P}_{\mathrm{st}}$ (calculated in a 10-minute time frame). 
Table 10. Flicker: China's Standards

\begin{tabular}{|c|c|c|}
\hline Standard & Sec. & Requirement \\
\hline GB/T 19963 & 11.2 & $\begin{array}{l}\text { The interference value for the flicker at a WPP's POI shall meet the } \\
\text { requirements of GB/T 12326, and the limit of the long-term flicker value, PIt, } \\
\text { caused by a WPP shall be assigned according to the ratio of the installed } \\
\text { capacity of the WPP to the total capacity of the interference sources at the } \\
\text { POI. }\end{array}$ \\
\hline NB/T 31003-2011 & 5.4 & $\begin{array}{l}\text { A WPP's access PCC flicker interference values should meet the demands } \\
\text { of GB/T 12326-2008. Long-term flicker values caused by a WPP at the PCC } \\
\text { should be in accordance with the ratio of a WPP's installed capacity to the } \\
\text { total capacity of interference sources at the POI. }\end{array}$ \\
\hline
\end{tabular}

Table 11. Flicker: U.S. Standards

\begin{tabular}{|c|c|c|}
\hline Standard & Sec. & Requirement \\
\hline FERC LGIA & 9.7 .6 & $\begin{array}{l}\text { Compliance with American National Standards Institute Standarc } \\
\text { C84.1-1989, } 7 \text { in accordance with IEEE Standard } 519 \text {, or any } \\
\text { applicable superseding electric industry standard }\end{array}$ \\
\hline NERC & & No \\
\hline ERCOT & & No \\
\hline $\begin{array}{l}\text { ISO-NE Large Generator } \\
\text { Interconnection Procedure }\end{array}$ & 9.7 .6 & $\begin{array}{l}\text { Compliance with American National Standards Institute Standaro } \\
\text { C84.1-1989, in accordance with IEEE Standard } 519 \text {, or any } \\
\text { applicable superseding electric industry standard }\end{array}$ \\
\hline
\end{tabular}

\subsubsection{Summary of the Comparison}

Although China's standards require a limit for the long-term flicker value, $\mathrm{P}_{1 t}$, they contain no requirements for the short-term flicker value, $\mathrm{P}_{\text {st }}$.

\subsubsection{Voltage Deviation}

For voltage deviation, China's standards require that the sum of the absolute values of the positive and negative voltage deviations at the POI do not exceed $10 \%$ of the nominal voltage; during normal operation, the voltage deviation should be within $-3 \%-+7 \%$ of the nominal voltage. NERC Standard VAR-001-4, "Voltage and Reactive Control," requires each transmission operator to specify a system-wide voltage schedule as part of its plan to operate within system operating limits and interconnection reliability operating limits and to provide the voltage schedule to its reliability coordinator and adjacent transmission operators upon request. In addition, Standard VAR-001-4 requires each transmission operator to schedule sufficient reactive resources to regulate voltage levels and to operate or direct the operation of devices to regulate transmission voltage and reactive flows.

\footnotetext{
7 “American National Standard for Electric Power Systems and Equipment_Voltage Ratings." This standard establishes nominal voltage ratings and operating tolerances for $60-\mathrm{Hz}$ electric power systems that are $>100 \mathrm{~V}$ and $\leq 230 \mathrm{kV}$.
} 
Table 12. Voltage Deviation: China's Standards

\begin{tabular}{lrl}
\hline Standard & Sec. & Requirement \\
\hline GB/T 19963 & 11.1 & $\begin{array}{l}\text { The sum of the absolute values of the positive and negative voltage } \\
\text { deviations at a POI shall not be more than } 10 \% \text { of the nominal voltage; } \\
\text { during normal operation, the voltage deviation shall be within }-3 \%-+7 \% \text { of } \\
\text { the nominal voltage. }\end{array}$ \\
NB/T 31003-2011 & $4.0 .4 \begin{array}{l}\text { When the common grid voltage is within the normal range, WPPs should } \\
\text { control the grid voltage within -3\%-+7\% of the nominal voltage. }\end{array}$ \\
\hline
\end{tabular}

Table 13. Voltage Deviation: U.S. Standards

\begin{tabular}{lll}
\hline Standard & Sec. & Requirement \\
\hline FERC Order No. 661/661A & & Specified as the voltage ride-through profile \\
NERC & VAR-001-4 & NERC Standard VAR-001-4 \\
ERCOT & & In compliance with NERC \\
ISO-NE & 3.5 & Specified based on NERC Standard VAR-001-4 \\
\hline
\end{tabular}

Table 14. Summary of the Comparison of the Standards for Voltage Deviation

\begin{tabular}{lll}
\hline & China's Standards & U.S. Standards \\
\hline \multirow{2}{*}{ Voltage deviation } & $\pm 10 \%$ & Steady state: $\pm 5.0 \%$ \\
& & Temporary/transients: $\pm 10.0 \%>161 \mathrm{kV}: 2.5 \%$ \\
\hline
\end{tabular}

\subsubsection{Voltage Imbalance}

An unbalanced condition in an electric power system is often caused by untransposed lines, unbalanced loads, unbalanced system faults, breaker malfunctions, and open phases. The ability of a generator to accommodate unbalanced currents is specified by IEEE Standard C50.12 ${ }^{8}$ and IEEE Standard C50.13 ${ }^{9}$ in terms of negative-sequence current. China's standards comply with GB/T 15543-2008: Power Quality_Three-Phase Voltage Unbalance. ${ }^{10}$

\footnotetext{
8 "IEEE Standard for Salient-Pole 50-Hz and 60-Hz Synchronous Generators and Generator/Motors for Hydraulic Turbine Applications Rated 5 MVA and Above"

9 "IEEE Standard for Cylindrical-Rotor 50-Hz and 60-Hz Synchronous Generators Rated 10 MVA and Above"

${ }^{10}$ This standard establishes the limitation, calculation, and measurement method for unbalanced three-phase voltage.
} 
Table 15. Voltage Imbalance: China's Standards

\begin{tabular}{|c|c|c|}
\hline Standard & Sec. & Requirement \\
\hline GB/T 19963 & 10.1 .2 & $\begin{array}{l}\text { When a three-phase voltage imbalance factor at a POI meets the } \\
\text { requirements of GB/T } 15543 \text {, the wind turbine in the WPP shall be } \\
\text { able to operate normally. }\end{array}$ \\
\hline NB/T 31003-2011 & 5.4 .1 & $\begin{array}{l}\text { When a three-phase voltage imbalance at a POI satisfies GB/T } \\
15543-2008, \text { the wind turbine in the WPP shall be able to operate } \\
\text { normally. }\end{array}$ \\
\hline
\end{tabular}

Table 16. Summary of the Comparison of the Standards for Voltage Imbalance

\begin{tabular}{lll}
\hline China's Standards & U.S. Standards \\
\hline & Negative sequence voltage & There is no relevant requirement among \\
& imbalance: $<2 \%$ & the standards in this study. NERC's IVGTF \\
Voltage imbalance & recommends that PRC-02411,12 should \\
& Short term: $<4 \%$ & clearly define performance requirements \\
& Caused by user: & for unbalanced as well as balanced faults. \\
& Long term: $<1.3 \%$ & The specification for voltage magnitude \\
Short term: $<2.6 \%$ & should define what voltage metric is \\
& applicable.
\end{tabular}

\subsubsection{Voltage Variation}

The U.S. standard for voltage variation (see Section 2.2.3) is based on NERC Standard VAR001-4, "Voltage and Reactive Control," and the regional reliability organizations (ERCOT, Western Electricity Coordinating Council). China's standards have quantitative requirements.

Table 17. Voltage Variation: China's Standards

\begin{tabular}{lll}
\hline Standard & Sec. & Requirement \\
\hline GB/T 19963 & & No \\
NB/T 31003-2011 & 5.4 .2 & $\begin{array}{l}\text { At a WPP's POI, variation in voltage, } d(\%) \text {, caused by wind power } \\
\text { should meet the specifications shown in the table below. }\end{array}$ \\
\hline
\end{tabular}

\footnotetext{
${ }^{11}$ Standard PRC-024-1(X), "Generator Performance During Frequency and Voltage Excursions." This standard ensures that generating units remain connected during frequency and voltage excursions and ensures that expected generating unit performance during frequency and voltage excursions is communicated to reliability coordinators, planning coordinators, transmission operators, and transmission planners for accurate system modeling.

${ }^{12}$ Standard PRC-024-2, "Generator Frequency and Voltage Protective Relay Settings." This standard ensures that generator owners set their generator protective relays such that generating units remain connected during defined frequency and voltage excursions.
} 
Table 18. Voltage Variation Specifications: China's Standards

\begin{tabular}{ll}
\hline $\begin{array}{l}\text { Frequency of Variations in Voltage, } \\
\boldsymbol{r} \text { (No. of Times/Hour) }\end{array}$ & $\begin{array}{l}\text { Variation in } \\
\text { Voltage, } \boldsymbol{d}(\%)\end{array}$ \\
\hline$r \leq 1$ & 3 \\
$1<r \leq 10$ & 2.5 \\
$10<r \leq 100$ & 1.5 \\
$100<r \leq 1,000$ & 1
\end{tabular}

Note: $d$ represents the voltage variations, which is the difference between two adjacent extreme values on the root mean square voltage $\left(\mathrm{V}_{\mathrm{rms}}\right)$ curve and is expressed as a percentage of the system's nominal voltage. $r$ represents the frequency of variations in voltage, which is the number of times variations in voltage occur per unit of time. (Each voltage change from low to high or high to low is counted as one variation.) For voltage variations in different directions back and forth, if the interval is less than $30 \mathrm{~ms}$, then only one variation is counted.

\subsection{Active Power/Reactive Power}

All relevant standards in the United States and China have detailed active power/reactive power requirements. Comparisons of the commonalities and differences are found and detailed below.

\subsubsection{Active Power}

Standards in both China and the United States specify active power control and ramp rate limits. China's standards have additional requirements for active power control during emergency grid conditions. China's standards for active power requirements in a WPP include three main aspects: (1) power regulation capability of a WPP's active power, (2) the ramp rate limit of a WPP's active power, (3) the control of active power of a WPP under an emergency power system condition. Note that the term active power is synonymous with real power and power.

In the United States, ISO-NE requires the active power output from a WPP to be adjustable in real time. In addition, to support frequency regulation, the active power output must be adjustable and its ramp rate shall be limited, and the WPP shall respond to the automatic generation control command signal [15]. ERCOT requires active power control for all generating resources. Frequency response from a wind turbine is required to support frequency dips only when WPPs are curtailed (i.e., the WPP has additional reserve power because it generates less than the available wind power) [16]. Compared to U.S. standards, the active power control requirements of WPPs in China are relatively straightforward.

Table 19. Active Power Control: China's Standards

\begin{tabular}{|c|c|c|}
\hline Standard & Sec. & Requirement \\
\hline \multirow{3}{*}{ GB/T 19963} & & $\underline{5.1 \text { Basic requirements }}$ \\
\hline & 5 & $\begin{array}{l}\text { 5.1.1 WPPs shall meet the requirements of } D L / T 1040^{13} \text { and have the } \\
\text { capability to participate in power system frequency regulation, peak } \\
\text { power regulation, and power reserve. }\end{array}$ \\
\hline & & $\begin{array}{l}\text { 5.1.2 WPPs shall be equipped with an active power control system } \\
\text { and have active power regulating capability. }\end{array}$ \\
\hline
\end{tabular}




\begin{tabular}{|c|c|c|}
\hline \multirow[t]{12}{*}{ Standard } & \multirow[t]{12}{*}{ Sec. } & \multirow{2}{*}{$\begin{array}{l}\text { Requirement } \\
5.1 .3 \text { When the active power of a WPP is more than } 20 \% \text { of the total } \\
\text { rated capacity, all wind turbines in the WPP shall implement the } \\
\text { continuous smooth regulation of active power and participate in the } \\
\text { active power control of the power system. }\end{array}$} \\
\hline & & \\
\hline & & $\begin{array}{l}\text { 5.1.4 WPPs shall be able to receive and automatically enforce the } \\
\text { control command for active power and the power ramp rate (dP/dt) } \\
\text { issued by the power system dispatch center. The active power and the } \\
\text { ramp rate of the WPP shall be consistent with the references (for } P \\
\text { and dP/dt) issued by the power system dispatch center. }\end{array}$ \\
\hline & & 5.2 Ramp rate $(\mathrm{dP} / \mathrm{dt})$ during normal operation \\
\hline & & $\begin{array}{l}\text { 5.2.1 The ramp rate of a WPP includes a 1-minute ramp rate and a 10- } \\
\text { minute ramp rate. During the start-up of a WPP and wind speed } \\
\text { increase, the ramp rate of the WPP shall meet the requirements for } \\
\text { the safe and stable operation of the power system. Its limits shall be } \\
\text { determined by the power system dispatch center according to the } \\
\text { frequency regulation characteristics of the connected power system. }\end{array}$ \\
\hline & & $\begin{array}{l}\text { 5.2.2 The recommended values for the limit of the ramp rate of a WPP } \\
\text { are detailed in GB/T 19963, which are also applicable to the normal } \\
\text { shutdown of a WPP. There may be conditions when the ramp rate of } \\
\text { the WPP exceeds the maximum ramping limit; these conditions may } \\
\text { be caused by wind speed drops or wind speed exceeding the cut-out } \\
\text { wind speed. }\end{array}$ \\
\hline & & $\underline{5.3 \text { Emergency control }}$ \\
\hline & & $\begin{array}{l}\text { 5.3.1 During a severe power system disturbance or emergency } \\
\text { operation, a WPP shall rapidly control its active power output } \\
\text { according to the command of the power system dispatch center. If } \\
\text { necessary, the active power of the WPP may be rapidly and } \\
\text { automatically reduced through the automatic safety device or the WPP } \\
\text { may be disconnected from the grid. On these occasions, the ramp rate } \\
\text { of the output power of the WPP is allowed to exceed the maximum } \\
\text { ramp rate limit specified by the power system dispatch center. }\end{array}$ \\
\hline & & $\begin{array}{l}\text { 1. The active power of a WPP shall be reduced during a severe } \\
\text { disturbance or special operation mode to prevent overloading } \\
\text { the transmission components (transformer, switchgear, etc.) } \\
\text { and ensure power system stability. }\end{array}$ \\
\hline & & $\begin{array}{l}\text { 2. When the frequency of a power system is higher than than } \\
50.2 \mathrm{~Hz} \text {, the active power of the WPP shall be reduced } \\
\text { according to the command of the power system dispatch } \\
\text { center or the entire WPP shall be disconnected from the grid } \\
\text { during a severe disturbance. }\end{array}$ \\
\hline & & $\begin{array}{l}\text { 3. If the operation of a WPP endangers the safety and stability of } \\
\text { a power system during a power system disturbance or } \\
\text { emergency circumstances, the WPP shall be temporarily } \\
\text { disconnected from the grid by the power system dispatch } \\
\text { center based on the requirements. }\end{array}$ \\
\hline & & $\begin{array}{l}\text { 5.3.2 After the power system recovers from the disturbance to normal } \\
\text { operation, the WPP shall be reconnected according to the dispatch } \\
\text { command. }\end{array}$ \\
\hline & & 5.1 Active power control of a WPP \\
\hline NB/T 31003-2011 & 5.1 and 6.1 & $\begin{array}{l}\text { 5.1.1 The active power of a WPP should have power regulation } \\
\text { capabilities (to deploy the active power control system based on an }\end{array}$ \\
\hline
\end{tabular}




\begin{tabular}{ll}
\hline Standard & Requirement \\
\hline active power control signal received). & 5.1 .2 The ramp rate limit of the active power of a WPP should be \\
coordinated with the power system frequency regulation ability and the \\
fixed regulating properties of other power plants. \\
5.1 .3 If a system's frequency regulation capacity is insufficient, the \\
active power of the WPP could be reduced. \\
5.1.4 During a power system failure or during a specific critical \\
condition, the WPP can be disconnected from the grid to ensure the \\
reliability and stability of the grid. When the power system has \\
returned to normal operation, the WPP should be reconnected to the \\
grid. \\
6.1 Active power control of a WTG \\
6.1.1 WTGs should have active power controllability that receives and \\
executes the reference power based on control signals sent by the \\
supervisory control of the WPP. When the active power is more than \\
$20 \%$ of its rated value, it should have a continuous and smooth active \\
power regulation capability. \\
6.1.2 WTGs should have local and remote active power control \\
capabilities. \\
\end{tabular}

Table 20. Active Power Control: U.S. Standards

\begin{tabular}{|c|c|c|}
\hline Standard & Sec. & Requirement \\
\hline FERC Order No. 661 & & No \\
\hline FERC Order No. $661 \mathrm{~A}$ & & No \\
\hline ERCOT & & No \\
\hline \multirow{11}{*}{ ISO-NE } & \multirow{11}{*}{$\begin{array}{l}2.1 .3 \\
\text { and } \\
3.4\end{array}$} & 2.1.3 Active power control recommendations \\
\hline & & 2.1.3.1 Engage with FERC and NERC. \\
\hline & & $\begin{array}{l}\text { - ISO-NE should stay engaged with the nascent NERC debates } \\
\text { and provide inputs as necessary. }\end{array}$ \\
\hline & & $\begin{array}{l}\text { 2.1.3.2 Require curtailment capability, but avoid requirements for } \\
\text { excessively fast response. }\end{array}$ \\
\hline & & $\begin{array}{l}\text { - Wind generation can respond rapidly to instructions to reduce } \\
\text { power output or relax curtailments. }\end{array}$ \\
\hline & & - A $\Delta 10 \% /$ second for rate of response to a step command to \\
\hline & & $\begin{array}{l}\text { response to step instructions should not be confused with the } \\
\text { deliberate imposition of ramp rate limits. }\end{array}$ \\
\hline & & $\begin{array}{l}\text { 2.1.3.3 Require the capability to limit the rate of increase of power } \\
\text { output. }\end{array}$ \\
\hline & & $\begin{array}{l}\text { - WPPs should be required to have the capability to limit the rate } \\
\text { of power increase. }\end{array}$ \\
\hline & & $\begin{array}{l}\text { 2.1.3.4 Encourage the capability to accept automatic generation control } \\
\text { signals. }\end{array}$ \\
\hline & & 2.1.3.5 Encourage or mandate the reduction of active power in \\
\hline
\end{tabular}




\begin{tabular}{|c|c|c|}
\hline Standard & Sec. & Requirement \\
\hline & & $\begin{array}{l}\text { response to high frequencies. } \\
\text { ISO-NE should encourage WPPs to provide overfrequency } \\
\text { droop response of similar character to that of other } \\
\text { synchronous machine governors. }\end{array}$ \\
\hline & & $\begin{array}{l}\text { 2.1.3.6 Consider requiring the capability to provide an increase of } \\
\text { active power for low frequencies. }\end{array}$ \\
\hline & & $\begin{array}{l}\text { ISO-NE should consider requiring WPPs to have the capability } \\
\text { to provide this response, and then establish rules and possibly } \\
\text { compensation, for when such controls would be enabled. }\end{array}$ \\
\hline & & 2.1.3.7 Consider requiring inertial response in the near future. \\
\hline & & 3.4. Active power control \\
\hline & & $\begin{array}{l}\text { 3.4.1 Curtailment capability } \\
\text { - The capability to move active power output at rates on the } \\
\text { order of } 10 \% / \text { second in response to step changes in } \\
\text { curtailment (or dispatch) appear to be within several, if not } \\
\text { most, of the original equipment manufacturers' capabilities. }\end{array}$ \\
\hline & & 3.4.2 Ramp rate control \\
\hline & & $\begin{array}{l}\text { Because pitch-controlled WTGs can limit their active power } \\
\text { output, they are also capable of controlling the rate of change } \\
\text { of power output in some circumstances, including the rate of } \\
\text { increase of power when wind speed is increasing, the rate of } \\
\text { increase in power when a curtailment of power output is } \\
\text { released, and the rate of decrease in power when a curtailment } \\
\text { limit is engaged. }\end{array}$ \\
\hline & & $\begin{array}{l}\text { - These functions could be implemented at either the level of an } \\
\text { individual turbine or a plant. }\end{array}$ \\
\hline & & $\begin{array}{l}\text { - Specifically, a short window (typically } 1 \text {-minute) ramp rate limit } \\
\text { addresses possible limitations in system regulation capability. A } \\
\text { longer window (typically } 10 \text { minutes) addresses possible } \\
\text { limitations in grid load-following capability. }\end{array}$ \\
\hline & & 3.4.3 Accepting automatic generation control instructions \\
\hline & & $\begin{array}{l}\text { - The range and minimum speed of response must be consistent } \\
\text { with the dynamic characteristics of the available wind } \\
\text { generation. }\end{array}$ \\
\hline
\end{tabular}

\subsubsection{Summary of the Comparison}

China's standards and the U.S. standards specify active power control and ramp rate limits in great detail. China's standards have additional requirements for active power control during emergency grid conditions.

China's standards for active power control include three main aspects: (1) the regulating capability of a WPP's active power, (2) the limit on the rate of change of a WPP's active power, and (3) the control of active power of a WPP during emergency power system conditions. In the United States, ISO-NE requires that the active power output from WPPs shall be adjustable in real time. In addition, when grid frequency fluctuates, the active power output and its ramp rate shall be limited, and WPPs shall act according to the automatic generation control command signal. 
Table 21. Summary of the Comparison of the Standards for Active Power Control

\begin{tabular}{llllll}
\hline & $\begin{array}{l}\text { Normal } \\
\text { Frequency Range }\end{array}$ & $\begin{array}{l}\text { Max. Cut-Out } \\
\text { Frequency }\end{array}$ & $\begin{array}{l}\text { Min. Cut-Out } \\
\text { Frequency }\end{array}$ & $\begin{array}{l}\text { Regulation } \\
\text { Range of } \\
\text { Active Power }\end{array}$ & $\begin{array}{l}\text { Speed of } \\
\text { Regulation of } \\
\text { Active Power }\end{array}$ \\
\hline China & $49.5-50.2 \mathrm{~Hz}$ & $50.2 \mathrm{~Hz}$ & $48 \mathrm{~Hz}$ & $20 \%-100 \%$ & None \\
$\begin{array}{l}\text { United } \\
\text { States }\end{array}$ & & & & $20 \%-100 \%$ & $10 \% /$ second \\
\hline
\end{tabular}

\subsubsection{Reactive Power}

In accordance with China's GB/T 19963-2011 requirements, WPPs should have reactive power control capabilities and be equipped with voltage control systems. Turbines should be capable of dynamically controlling power factors within the range from 0.95 lagging to 0.95 leading. When the reactive capacity of a wind turbine cannot meet the system voltage regulation requirements, the reactive compensation device with proper capacity shall be installed at the WPP; if necessary, a dynamic reactive compensation device shall be installed [8].

In 2016, FERC issued Order 827 to require nonsynchronous generation and synchronous generation to provide reactive power as a condition of interconnection. The U.S. standards require power plants to be capable of continuous operation within the power factor range from 0.95 leading to 0.95 lagging. ERCOT proposes that WTGs should not be required to provide reactive power when their output is less than $10 \%$ of nameplate capacity. ISO-NE points out that different types of WTGs have quite different reactive power capabilities.

Table 22. Reactive Power: China's Standard

\begin{tabular}{|c|c|c|}
\hline Standard & Sec. & Requirement \\
\hline & & 7. Reactive power capacity of a WPP \\
\hline & & 7.1 Reactive power supply \\
\hline & & $\begin{array}{l}\text { 7.1. } 1 \text { The sources of the reactive power supply in a WPP include } \\
\text { the wind turbine and reactive compensation device. The wind } \\
\text { turbine installed in the WPP shall ensure that the power factor } \\
\text { shall be dynamically adjustable within the range from } 0.95 \text { leading } \\
\text { to } 0.95 \text { lagging. }\end{array}$ \\
\hline & & $\begin{array}{l}\text { 7.1.2 A WPP first takes full advantage of the reactive capacity } \\
\text { and regulation ability of the wind turbines. When the reactive } \\
\text { capacity of the wind turbines cannot meet the system voltage } \\
\text { regulation requirement, a plant-level reactive compensation }\end{array}$ \\
\hline GB/T 19963 & 7 & $\begin{array}{l}\text { device with the proper capacity shall be installed at the POI of the } \\
\text { WPP; if necessary, a dynamic reactive compensation device shall } \\
\text { be installed. }\end{array}$ \\
\hline
\end{tabular}

7.2 Reactive capacity provision

7.2.1 The reactive capacity of a WPP shall be configured according to the basic balancing principle of "layering (voltage) and zoning (electricity)," and it shall maintain the reactive power reserve requirements.

7.2.2 For a WPP directly connected to the grid, the equipped capacitive reactive capacity shall be able to compensate for the sum of the inductive reactive power of the collector system and the main transformer in the WPP and half of the inductive reactive 


\begin{tabular}{ll}
\hline Standard & Requirement \\
\hline & power of the transmission line of the WPP during the rated power \\
of the WPP. The equipped inductive reactive capacity shall be \\
able to compensate for the capacitive charging reactive power of \\
the WPP and half of the charging reactive power of the \\
transmission line of the WPP. \\
7.2.3 For a WPP in the WPP group boosted through a 220-kV (or \\
$330-\mathrm{kV}$ ) wind-collecting system to a 500-kV (or $750-\mathrm{kV}$ ) voltage \\
level and connected to the public power grid, the capacitive \\
reactive capacity shall be able to compensate for the sum of the \\
inductive reactive power of the collecting system and the main \\
transformer in the WPP and the inductive reactive power of the \\
transmission line of the WPP during the full output of the WPP. \\
The equipped inductive reactive capacity shall be able to \\
compensate for the capacitive charging reactive power of the \\
WPP and the charging reactive power of the transmission line of \\
the WPP. \\
7.2.4 The type and capacity range of the reactive power device to \\
be equipped in the WPP shall be determined by the specific study \\
on the reactive power and voltage for connecting the WPP to the \\
power system according to the actual connection situation of the \\
WPP.
\end{tabular}

NB/T 31003-2011

5.3

6.2

\subsection{Reactive power of a WPP}

5.3.1 WPPs should have reactive power control abilities and be equipped with reactive voltage control systems.

5.3.2 A WPP's step-up substation should adopt on-load tap changer regulating transformers by having the main transformer's tap adjust the entire WPP's voltage to ensure that the plant's WTGs operate normally.

5.3.3 WPPs must take advantage of utilizing the reactive power capacity and regulation ability of WPPs. Although the reactive power capacity of a WTG does not need to satisfy a system's voltage regulation demands, WPPs should collectively implement compensation mechanisms that satisfy their reactive power needs based on a specific study of the reactive power requirement for interconnecting WPPs.

\subsection{Reactive power controls}

6.2.1 WTGs should satisfy dynamically adjustable power factors within a range from 0.95 leading to 0.95 lagging.

Table 23. Reactive Power: U.S. Standards

\begin{tabular}{lll}
\hline Standard & Sec. & Requirement \\
\hline A WPP shall maintain a power factor within the range from 0.95 \\
FERC Order & IV. 74 & $\begin{array}{l}\text { leading to 0.95 lagging, measured at the POI, unless the transmission } \\
\text { provider has a different power factor range. The standard is dynamic } \\
\text { and can be met using power electronics or fixed and switched } \\
\text { capacitors. The power factor equipment cannot be disabled while the } \\
\text { WPP is in operation. }\end{array}$
\end{tabular}




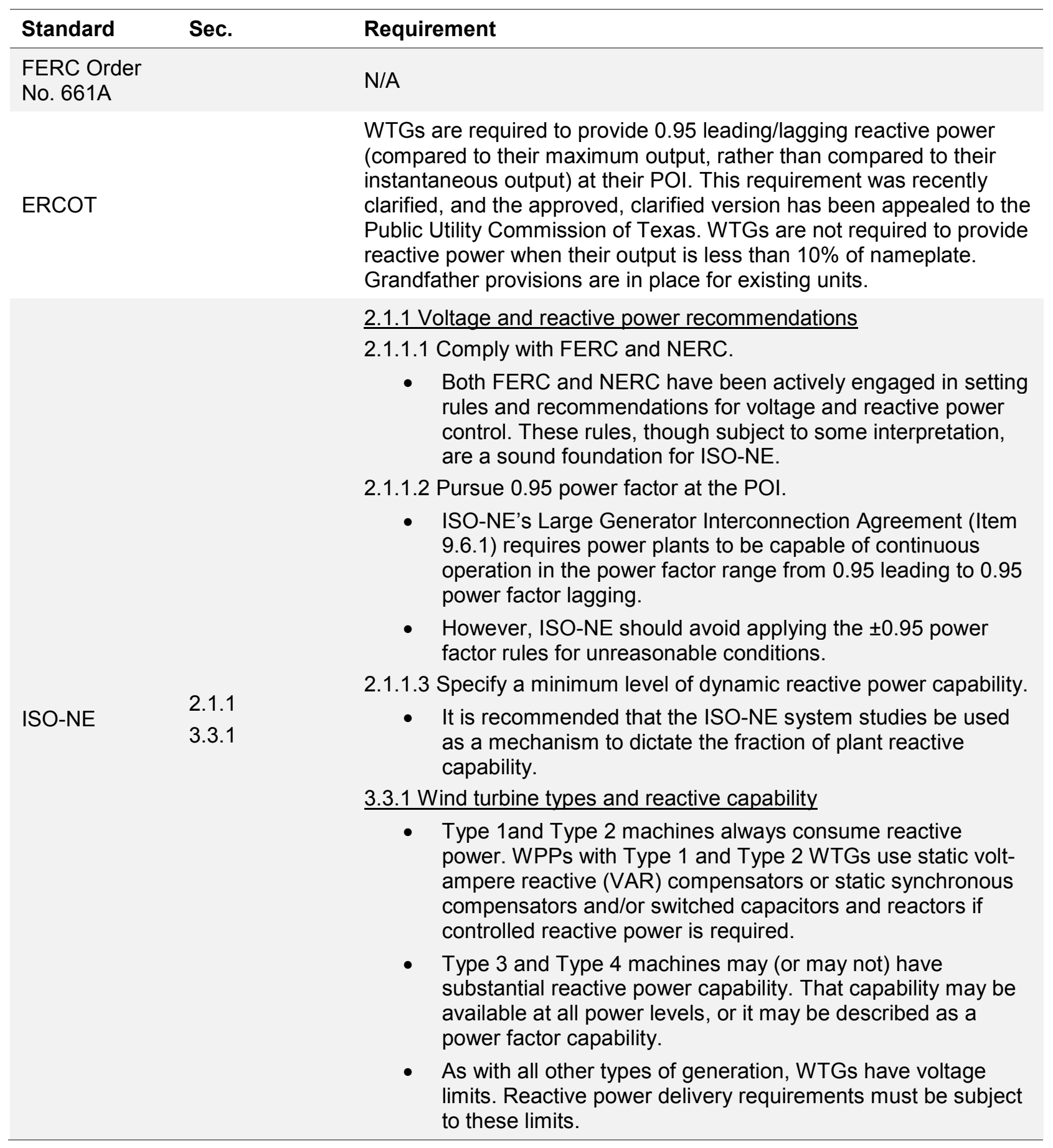

\subsubsection{Summary of the Comparison}

China's national standard requires wind turbines installed in a WPP to have power factors that are dynamically adjustable within the range from 0.95 leading to 0.95 lagging. China's industry standard has only qualitative requirements regarding a WPP's ability to control the reactive power and installation of the requisite reactive voltage control system. In addition, China's national standard specifies the reactive power sources and provision of reactive power capacity: when the reactive capacity of a wind turbine cannot meet the system voltage regulation 
requirements, a reactive compensation device with the proper capacity shall be collectively installed in the WPP; if necessary, a dynamic reactive compensation device shall be installed.

The three U.S. wind interconnection standards indicate that a WPP should maintain a power factor within the range from 0.95 leading to 0.95 lagging and a certain extent of voltage regulation at zero active power output. U.S. standards do not require all WPPs to have dynamic reactive power regulation; instead, this depends on the characteristics and structure of the electric power grid to which the concerned WPP is connected.

\subsection{Voltage Control}

According to China's standards, WPPs should be equipped with a reactive voltage control system with reactive power regulation and voltage control capacity. The WPP shall automatically regulate its delivered (or absorbed) reactive power to control the voltage at the POI, and the regulation speed and control accuracy should meet the power system's requirements for voltage regulation. The WPP should also be able to control the voltage at the POI within $97 \%-107 \%$ of the nominal voltage.

ISO-NE requires WPPs to have a voltage regulator and to operate in automatic voltage control mode. Requirements for voltage regulation should be relaxed or eliminated at low power output (less than approximately $20 \%$ of the WPP rating), and permissive reactive power range should be enforced. WTGs can provide smooth, fast voltage regulation by delivering controlled reactive power even when the wind turbines are not generating active power [15].

ERCOT's voltage control requirements apply to generating facilities larger than 20 MVA. ERCOT requires WPPs to have an automatic voltage regulator and to operate in automatic voltage regulation mode. ERCOT also provides seasonal voltage set points in coordination with transmission operators for all resources at the POI [16].

Table 24. Voltage Control: China's Standards

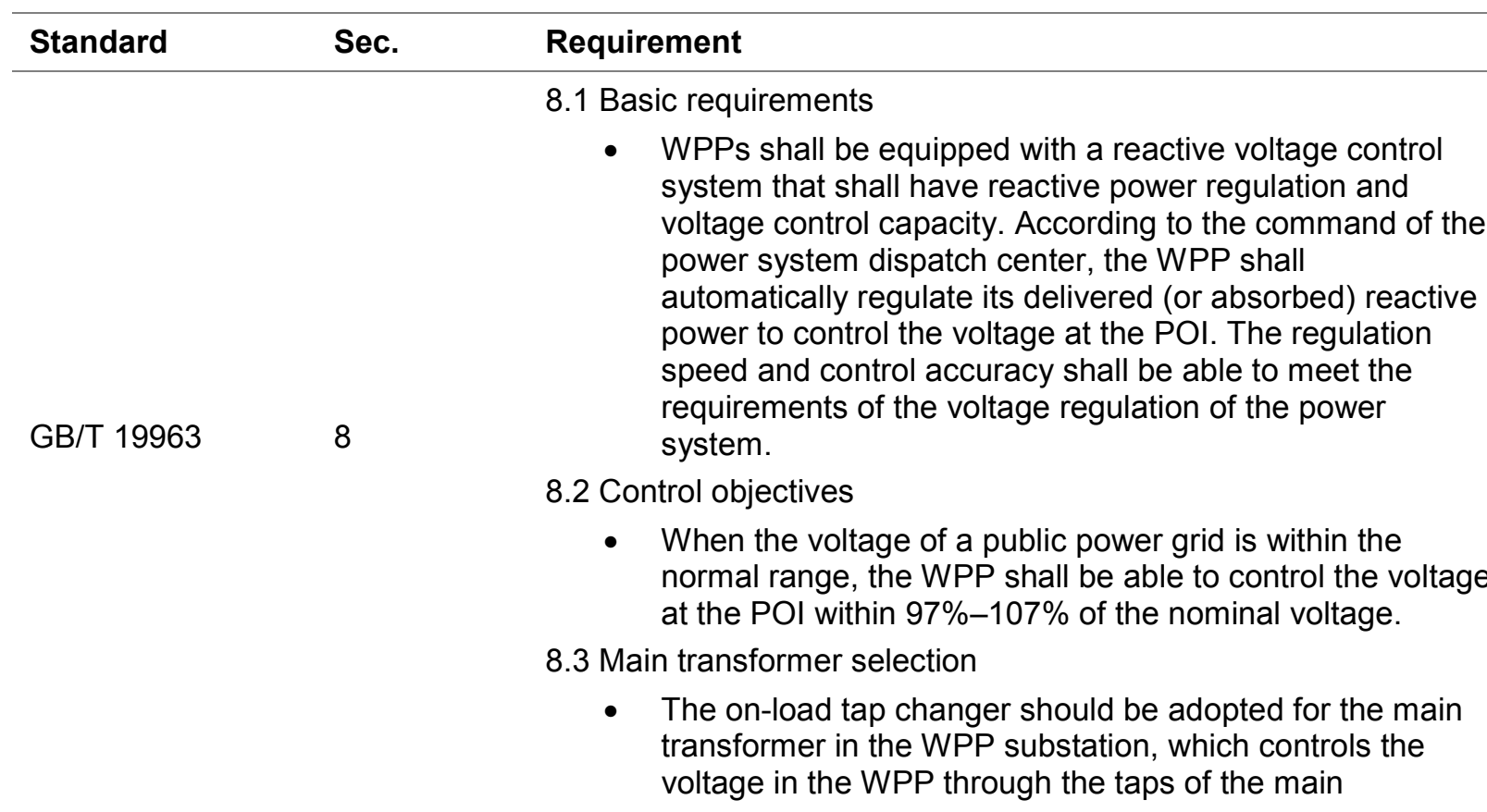




\begin{tabular}{lcl}
\hline Standard & Sec. & Requirement \\
& & $\begin{array}{l}\text { transformer and ensures normal operation of the wind } \\
\text { turbines in a WPP. }\end{array}$ \\
NB/T 31003-2011 & 4.0 .4 & $\begin{array}{l}\text { When the common grid voltage is within normal limits, WPPs } \\
\text { should control the grid voltage within the }-3 \%-+7 \% \text { voltage rating } \\
\text { range. }\end{array}$ \\
\hline
\end{tabular}

Table 25. Voltage Control: U.S. Standards

\begin{tabular}{|c|c|c|}
\hline Standard & Sec. & Requirement \\
\hline $\begin{array}{l}\text { FERC Order No. } \\
661 / 661 \mathrm{~A}\end{array}$ & A.ii. & $\begin{array}{l}\text { The WPP is required to provide sufficient dynamic voltage support } \\
\text { in lieu of the power system stabilizer and automatic voltage } \\
\text { regulation at the generator excitation system if the system impact } \\
\text { study deems this necessary. The voltage ride-through (voltage-time) } \\
\text { profile should be maintained. }\end{array}$ \\
\hline NERC & & $\begin{array}{l}\text { Standard PRC-024-2(X)—generator frequency and voltage } \\
\text { protective relay settings }\end{array}$ \\
\hline ERCOT & & $\begin{array}{l}\text { ERCOT requires WPPs to have an automatic voltage regulator and } \\
\text { to operate in automatic voltage regulation mode. ERCOT also } \\
\text { provides seasonal voltage set points that are developed in } \\
\text { coordination with the transmission operators for all resources at the } \\
\text { POI. }\end{array}$ \\
\hline \multirow{7}{*}{ ISO-NE } & \multirow{7}{*}{$\begin{array}{l}2.1 .1 \text { and } \\
3.3 .2\end{array}$} & $\begin{array}{l}\text { 2.1.1.5 Schedule voltages. } \\
\text { - ISO-NE's Large Generator Interconnection Agreement (Item } \\
\text { 9.6.2) requires WPPs to have a voltage regulator and to } \\
\text { operate in automatic voltage control mode. WPPs should be } \\
\text { subject to this same requirement, and they should respond } \\
\text { to voltage set-point (schedule) signals communicated from } \\
\text { the independent system operator to the WPP. } \\
\text { - WPPs are often connected to a weak portion of the grid, } \\
\text { and the selection of the appropriate voltage schedule can } \\
\text { improve the performance and security of the system. }\end{array}$ \\
\hline & & 2.1.1.8 Adopt permissive rules for low power. \\
\hline & & $\begin{array}{l}\text { Requirements for voltage regulation should be relaxed or } \\
\text { eliminated at low power output (less than approximately } \\
20 \% \text { of the plant rating), and permissive reactive power } \\
\text { range should enforced. }\end{array}$ \\
\hline & & $\begin{array}{l}\text { - This permissive interpretation means that a plant may } \\
\text { operate anywhere in the reactive power range } \\
\text { corresponding to } \pm 0.95 \text { power factor of } 20 \% \text { of plant } \\
\text { nameplate whenever the plant power output is less than } \\
20 \% \text { of its nameplate rating. }\end{array}$ \\
\hline & & $\begin{array}{l}\text { 2.1.2.5 Allow, or even encourage, reduced power output for deep } \\
\text { voltage events. }\end{array}$ \\
\hline & & $\begin{array}{l}\text { - During deep voltage depressions, it is physically difficult or } \\
\text { impossible to maintain active power injection to the grid. }\end{array}$ \\
\hline & & $\begin{array}{l}\text { - In addition to allowing active power to drop during voltage } \\
\text { depressions, New England should avoid excessively tight or } \\
\text { fast post-fault power recovery requirements. }\end{array}$ \\
\hline
\end{tabular}




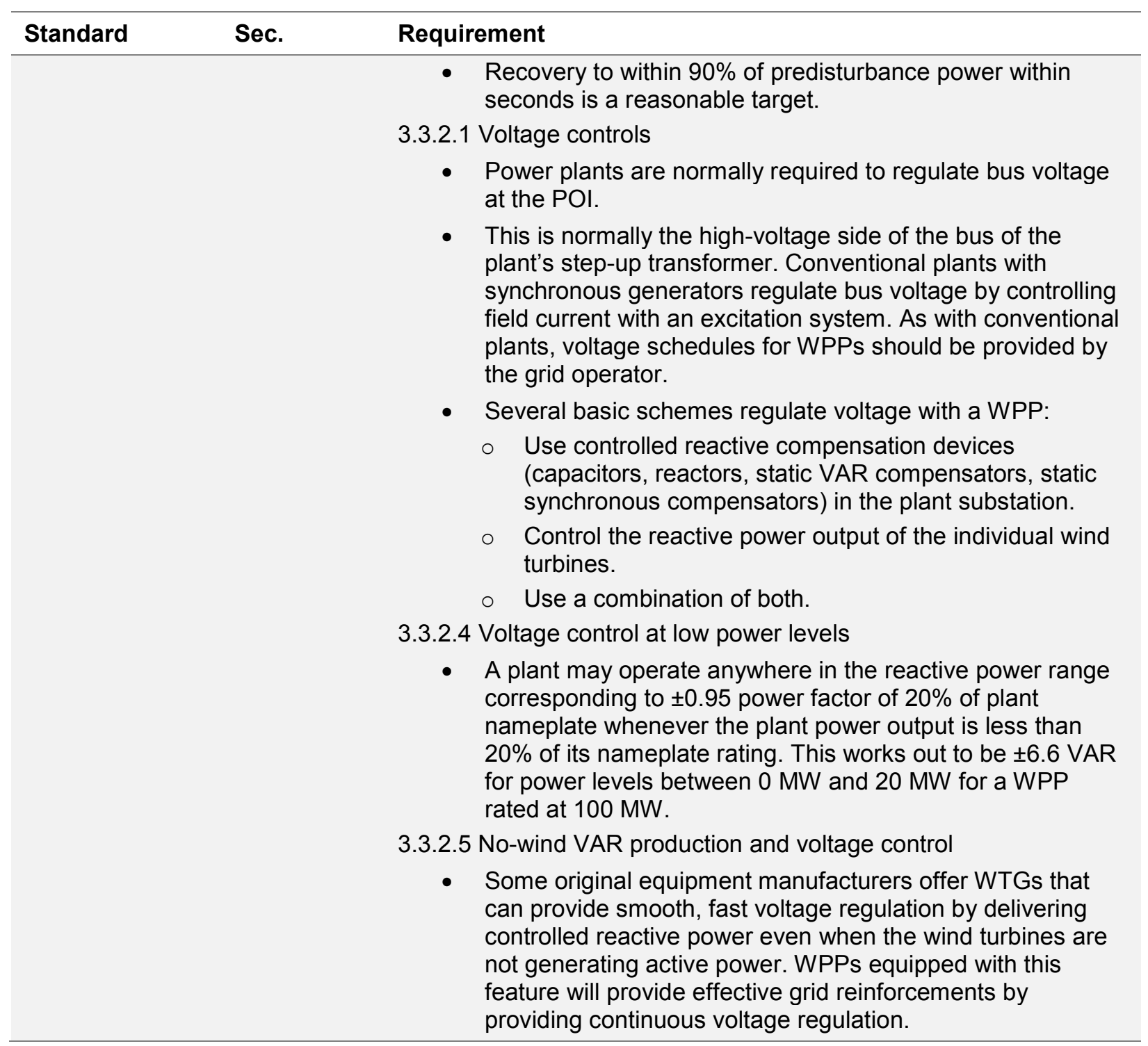

\subsubsection{Summary of the Comparison}

China's standards require WPPs to be equipped with a reactive voltage control system and have the ability to provide reactive power regulation and voltage control. According to the command of the power system dispatch center, the WPP shall automatically regulate its delivered (or absorbed) reactive power to control the voltage at the POI. The regulation speed and control accuracy shall be able to meet the requirements of voltage regulation of the power system. An on-load tap changer transformer should be used as the main transformer in a WPP substation in which the voltage in the WPP is controlled. This will ensure normal operation of the wind turbines in the WPP. The control objective is to ensure that the WPP's voltage at the POI is within $97 \%-107 \%$ of the nominal voltage when the public electric grid voltage is within normal operating range.

In the United States, ISO-NE requires WPPs to have a voltage regulator and to operate in automatic voltage control mode. Requirements for voltage regulation should be relaxed or 
eliminated at low power (less than approximately $20 \%$ of the plant rating), and the permissive reactive power range should be enforced. Fast voltage regulation can be realized by delivering controlled reactive power even when the wind turbines are not generating any active power.

\subsection{Active Power Feed-In at Overfrequency/Underfrequency}

China's standards make it necessary for WPPs to follow the instructions of the grid dispatch stations for active power feed-in at overfrequency/underfrequency. U.S. standards specify the technical requirements.

Table 26. Active Power Feed-In: China's Standards

\begin{tabular}{lll}
\hline Standard & Sec. & Requirement \\
\hline GB/T 19963 & 5.3 & $\begin{array}{l}\text { When the frequency of the power system is higher than } 50.2 \mathrm{~Hz}, \\
\text { the active power of the WPP shall be reduced according to the } \\
\text { command of the power system dispatch center, or the whole WPP } \\
\text { shall be cut off under the serious conditions. }\end{array}$ \\
NB/T 31003-2011 & 5.1 .3 & $\begin{array}{l}\text { If the system's frequency regulation capacity is insufficient, reduce } \\
\text { the active power of the WPP. }\end{array}$ \\
\hline
\end{tabular}

Table 27. Active Power Feed-In: U.S. Standards

\begin{tabular}{|c|c|c|}
\hline Standard & Sec. & Requirement \\
\hline $\begin{array}{l}\text { FERC Order No. } \\
661 / 661 \mathrm{~A}\end{array}$ & & No \\
\hline NERC & & $\begin{array}{l}\text { Standard PRC-024- } 1(X) \text { - generator frequency and voltage } \\
\text { protective relay settings }\end{array}$ \\
\hline & & Frequency response \\
\hline ERCOT & & $\begin{array}{l}\text { Frequency response from WTGs is required for low frequency only } \\
\text { when WPPs are curtailed. Wind units are required to provide } \\
\text { primary frequency response in response to high system frequency } \\
\text { similar to a thermal unit with a droop of } 5 \% \text {. }\end{array}$ \\
\hline \multirow{8}{*}{ ISO-NE } & \multirow{8}{*}{$\begin{array}{l}2.1 .3 .5 \\
2.1 .3 .6 \\
3.4 .4 .2 \\
3.4 .4 .3\end{array}$} & $\begin{array}{l}\text { 2.1.3.5 Encourage or mandate reduction of active power in } \\
\text { response to high frequencies. }\end{array}$ \\
\hline & & $\begin{array}{l}\text { ISO-NE should encourage WPPs to provide overfrequency droop } \\
\text { response of similar character to that of other synchronous machine } \\
\text { governors. }\end{array}$ \\
\hline & & $\begin{array}{l}\text { 2.1.3.6 Consider requiring the capability to provide and increase of } \\
\text { active power for low frequencies. }\end{array}$ \\
\hline & & $\begin{array}{l}\text { ISO-NE should consider requiring WPPs to have the capability to } \\
\text { provide this response, and then establish rules and possibly } \\
\text { compensation, for when such controls would be enabled. }\end{array}$ \\
\hline & & 3.4.4.2 Overfrequency response \\
\hline & & $\begin{array}{l}\text { When enabled, the response of the GE Wind CONTROL will rapidly } \\
\text { reduce power output for the duration of the overfrequency event. }\end{array}$ \\
\hline & & 3.4.4.3 Underfrequency and power reserve response \\
\hline & & $\begin{array}{l}\text { To allow for an increase in WPP active power output in response to } \\
\text { an underfrequency condition, some active power production must } \\
\text { be kept in reserve. }\end{array}$ \\
\hline
\end{tabular}




\subsubsection{Summary of the Comparison}

Table 28. Summary of the Comparison of the Standards for Active Power Feed-In

\begin{tabular}{|c|c|c|}
\hline & China's Standards & U.S. Standards \\
\hline \multirow{4}{*}{$\begin{array}{l}\text { Active power feed- } \\
\text { in at } \\
\text { overfrequency/ } \\
\text { underfrequency }\end{array}$} & GB/T 19963, Q/GDW 392-2009 & \multirow{4}{*}{$\begin{array}{l}\text { WTGs are required or } \\
\text { encouraged to provide primary } \\
\text { frequency response in } \\
\text { response to high or low } \\
\text { system frequency. }\end{array}$} \\
\hline & $\begin{array}{l}\text { When the frequency of the power system is higher } \\
\text { than } 50.2 \mathrm{~Hz} \text {, the active power of the WPP shall } \\
\text { be reduced according to the command of the } \\
\text { power system dispatch center, or the whole WPP } \\
\text { shall be cut off under serious conditions. }\end{array}$ & \\
\hline & NB/T 31003-2011 & \\
\hline & $\begin{array}{l}\text { If the system's frequency regulation capacity is } \\
\text { insufficient, reduce the active power of wind. }\end{array}$ & \\
\hline
\end{tabular}

\subsection{Frequency Range}

China's three standards each require WPPs to withstand an overfrequency or underfrequency event for a period of time. China's standards set $48 \mathrm{~Hz}, 49.5 \mathrm{~Hz}$, and $50.2 \mathrm{~Hz}$ as thresholds to determine wind turbine operation status. When the frequency of the electric power grid is in a normal state (i.e., between $49.5 \mathrm{~Hz}$ and $50.2 \mathrm{~Hz}$ ), WPPs should work in continuous operation mode. During overfreuqnecy, the WPP is required to have at least a few minutes of operating capability; however, China's standards contain no specific requirements for underfrequency (i.e., lower than $48 \mathrm{~Hz}$ ).

U.S. standards, on the other hand, do contain requirements for underfrequency events. Thresholds for operation range are set at $57.5 \mathrm{~Hz}, 58.0 \mathrm{~Hz}, 58.4 \mathrm{~Hz}$, and $59.4 \mathrm{~Hz}$. Further, requirements on frequency change rate have also been considered in U.S. standards (ISO-NE 3.2.4).

Table 29. Frequency Range: China's Standards

\begin{tabular}{|c|c|c|c|}
\hline Standard & Sec. & Requirement & \\
\hline \multirow{6}{*}{ GB/T 19963} & \multirow{6}{*}{10.2} & \multicolumn{2}{|c|}{$\begin{array}{l}\text { WPPs shall operate as required within the power system frequency } \\
\text { range, as shown in the table below. }\end{array}$} \\
\hline & & $\begin{array}{l}\text { Power System } \\
\text { Frequency Range }\end{array}$ & Requirements \\
\hline & & Less than $48 \mathrm{~Hz}$ & $\begin{array}{l}\text { Determined according to permissible } \\
\text { minimum operating frequency of the wind } \\
\text { turbines in a WPP }\end{array}$ \\
\hline & & $48 \mathrm{~Hz}-49.5 \mathrm{~Hz}$ & $\begin{array}{l}\text { When the frequency is lower than } 49.5 \\
\mathrm{~Hz} \text {, a WPP is required to have at least } 30 \\
\text { minutes of operating ability. }\end{array}$ \\
\hline & & $49.5 \mathrm{~Hz}-50.2 \mathrm{~Hz}$ & Continuous operation \\
\hline & & Higher than $50.2 \mathrm{~Hz}$ & $\begin{array}{l}\text { When the frequency is higher than } 50.2 \\
\mathrm{~Hz} \text {, a WPP is required to have at least } 5 \\
\text { minutes of operating ability and comply } \\
\text { with the reduced output or high cutter } \\
\text { strategy issued by the power system }\end{array}$ \\
\hline
\end{tabular}




\begin{tabular}{|c|c|c|c|}
\hline \multirow[t]{2}{*}{ Standard } & \multirow[t]{2}{*}{ Sec. } & \multicolumn{2}{|l|}{ Requirement } \\
\hline & & & $\begin{array}{l}\text { dispatch center. Wind turbines under the } \\
\text { stopped state cannot connect to the grid. }\end{array}$ \\
\hline \multirow{4}{*}{ NB/T 31003-2011 } & \multirow{4}{*}{6.3} & \multicolumn{2}{|c|}{$\begin{array}{l}\text { 6.3.1 When the variation of grid frequency is within the range from } \\
49.5 \mathrm{~Hz}-50.5 \mathrm{~Hz} \text {, WTGs should have continuous operating } \\
\text { capabilities. }\end{array}$} \\
\hline & & \multicolumn{2}{|c|}{$\begin{array}{l}\text { 6.3.2 When the grid frequency is lower than } 47.5 \mathrm{~Hz} \text {, a WTG's ability } \\
\text { to operate continuously depends on its permitted lowest frequency of } \\
\text { operation. }\end{array}$} \\
\hline & & \multicolumn{2}{|c|}{$\begin{array}{l}\text { 6.3.3 When the variation of the grid frequency is within the range } \\
\text { from } 49.5 \mathrm{~Hz}-50.5 \mathrm{~Hz} \text {, WTGs should have operating capabilities for } \\
\text { at least } 10 \text { minutes. }\end{array}$} \\
\hline & & \multicolumn{2}{|c|}{$\begin{array}{l}\text { 6.3.4 When the variation of the grid frequency is within the range } \\
\text { from } 50.5 \mathrm{~Hz}-51 \mathrm{~Hz} \text {, WTGs should have operating capabilities for at } \\
\text { least } 2 \text { minutes. }\end{array}$} \\
\hline
\end{tabular}

Table 30. Frequency Range: U.S. Standards

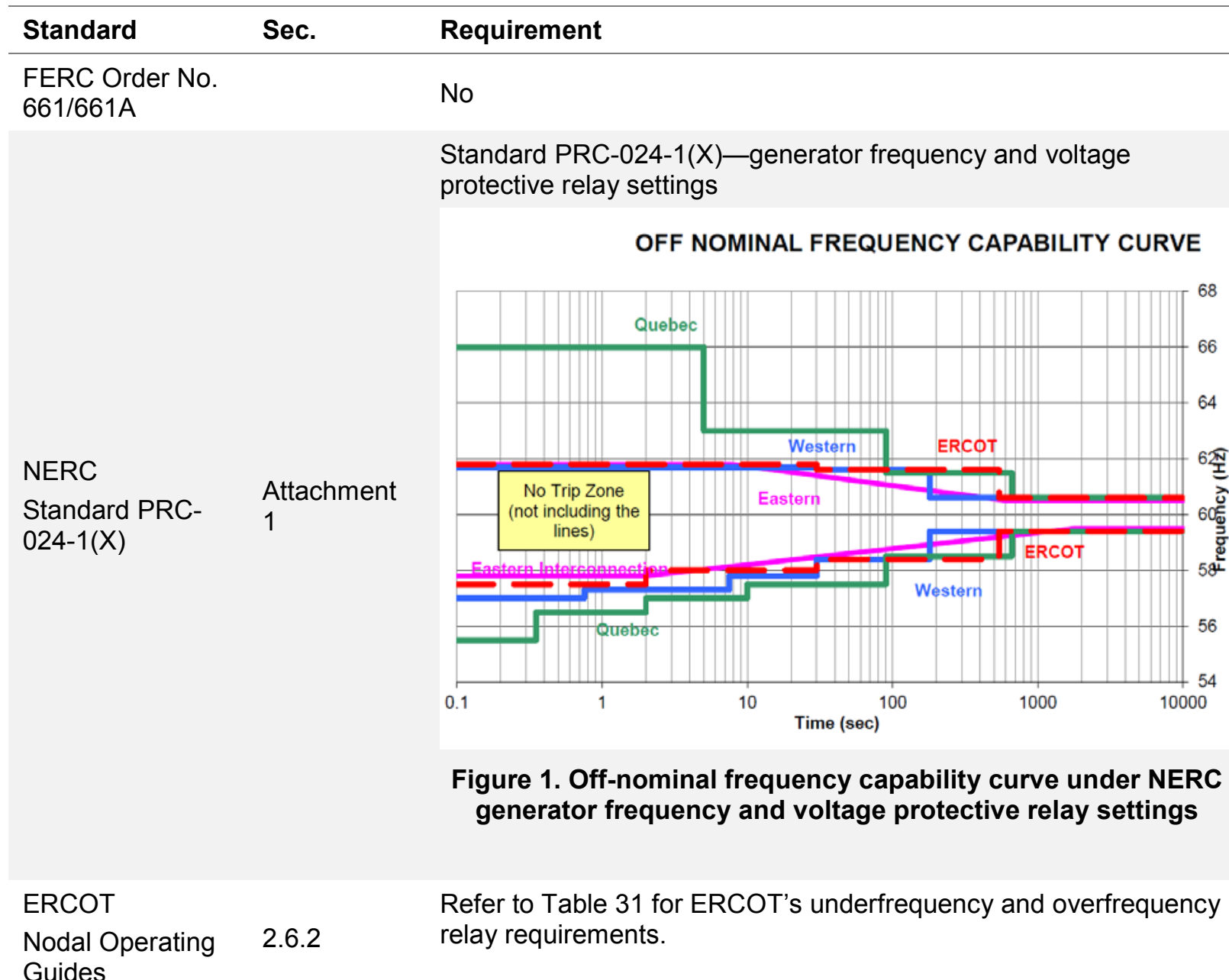




\begin{tabular}{|c|c|c|}
\hline \multirow{6}{*}{ ISO-NE } & \multirow{6}{*}{$\begin{array}{l}3.2 .3 \\
3.2 .4\end{array}$} & 3.2.3 Frequency tolerance \\
\hline & & $\begin{array}{l}\text { Present Northeast Power Coordinating Council, Inc., rules for } \\
\text { frequency ride-through are well suited to modern wind generation. }\end{array}$ \\
\hline & & 3.2.4.Rate of change of frequency \\
\hline & & Initial drops on the order of $1-2 \mathrm{~Hz} / \mathrm{s}$ can be found for severe \\
\hline & & events in big systems. Some small systems have mandated \\
\hline & & $\begin{array}{l}\text { tolerance to rates as fast as } 4 \mathrm{~Hz} / \mathrm{s} \text {, but such rates are found only in } \\
\text { small grids. Although this may be a reasonable requirement for } \\
\text { ISO-NE, it is not recommended that ISO-NE adopt any rate-of- } \\
\text { frequency requirements. }\end{array}$ \\
\hline
\end{tabular}

Table 31. ERCOT's Operating Guides 2.6.2 Underfrequency and Overfrequency Requirements

\begin{tabular}{ll}
\hline Frequency Range & Delay to Trip \\
\hline Higher than $59.4 \mathrm{~Hz}$ & No automatic tripping (continuous operation) \\
Higher than $58.4 \mathrm{~Hz}$ up to and including $59.4 \mathrm{~Hz}$ & Not less than 9 minutes \\
Higher than $58.0 \mathrm{~Hz}$ up to and including $58.4 \mathrm{~Hz}$ & Not less than 30 seconds \\
Higher than $57.5 \mathrm{~Hz}$ up to and including $58.0 \mathrm{~Hz}$ & Not less than 2 seconds \\
$57.5 \mathrm{~Hz}$ or lower & No time delay required \\
\hline
\end{tabular}

\subsection{Voltage Ride-Through Capability}

When the voltage at the POI drops to within a certain range caused by power system failures or disturbances, wind turbines with LVRT capabilities can operate uninterruptedly while maintaining their connection to the grid [13]. A wind turbine's LVRT capability helps ensure power system balance and maintain stable frequency during and after disturbances. When wind turbines do not have LVRT capability, WPPs may trip if a grid fault occurs [15].

China's standards require a wind turbine to remain connected when the voltage is reduced to 0.2 p.u. for up to 0.625 second, whereas U.S. standards have different requirements. In terms of active power restoration, China's national standard requires a restoration speed of $10 \% /$ second of the rated power; whereas in the United States, ISO-NE suggests a restoration time of 0.5 second. In terms of dynamic reactive power support, China's national standard requires a reactive current response time not longer than $75 \mathrm{~ms}$ and proposes detailed technical requirements and a calculation formula for the dynamic reactive current. In the United States, ISO-NE does not have requirements for the corresponding time of the dynamic reactive current, but it proposes qualitative requirements (rather than quantitative requirements) for dynamic reactive support.

\subsubsection{China's Standards}

China's requirements for the LVRT of a WPP are illustrated in the table below. When the voltage at the POI drops to $20 \%$ of the rated voltage, WTGs should ensure continuous operation with no disconnection for 0.625 second. When the voltage at the POI is able to recover to $90 \%$ of the rated voltage within 2 seconds after dropping, generators should ensure continuous operation with no disconnection. 
Table 32. LVRT Capability: China's Standards

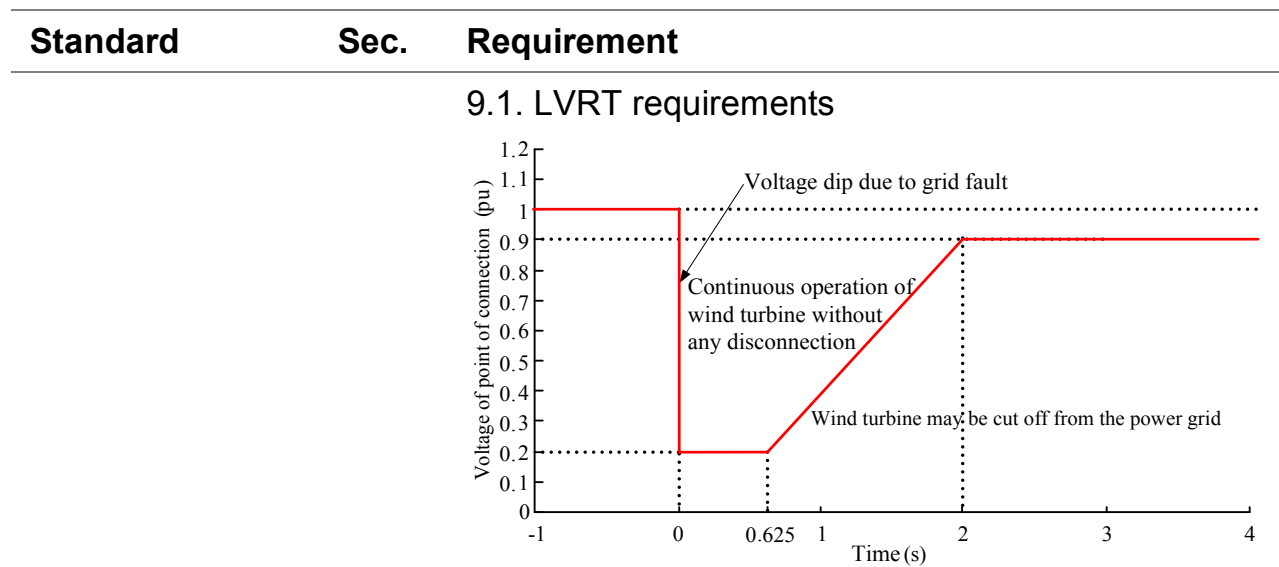

Figure 2. LVRT requirements for WPP interconnection in China (GB/T 19963)

1. When the voltage at the POI drops to $20 \%$ of the nominal voltage, the WTGs in the WPP shall ensure continuous operation with no disconnection for $625 \mathrm{~ms}$.

2. When the voltage at the $\mathrm{POI}$ is able to recover to $90 \%$ of the nominal voltage within 2 seconds after dropping, the WTGs in the WPP shall ensure continuous operation under no disconnection.

\subsection{Fault type and examination voltage}

GB/T 19963

Under various power system faults, if the measured voltage at the POI is on the voltage contour line or in the area above the contour line (as shown in the LVRT requirements in Figure 2), the wind turbine must ensure continuous operation with no disconnection; otherwise, the wind turbine is allowed to be cut off.

\subsection{Active recovery}

For the WPP not cut off during the fault period of the power system, the active power shall rapidly recover after the fault clearance, and it shall recover to the value before the fault with a power change rate of at least $10 \%$ of rated power per second since the fault clearance.

9.4 Dynamic reactive supporting capacity

For a WPP group with a total installed capacity of $1 \mathrm{GW}$ and more, when the power system voltage drops due to a three-phase short-circuit fault, each WPP shall have the following dynamic reactive supporting capacity during the LVRT process:

1. When the voltage at the POI of the WPP is within $20 \%-90 \%$ of the nominal voltage, the WPP shall be able to support the voltage recovery by injecting the reactive current. The dynamic reactive current control response time shall not be more than $75 \mathrm{~ms}$, and the duration time shall not be less than $550 \mathrm{~ms}$, because the voltage at the POI drops.

2. The dynamic reactive current injected to the power system by the WPP $I_{T} \geqslant 1.5 \times\left(0.9-U_{T}\right) I_{N},\left(0.2 \leqslant U_{T} \leqslant 0.9\right)$, where:

- $U_{T}$ : per-unit value of voltage at the POI

- $I_{\mathrm{N}}$ : rated current of the WPP. 


\begin{tabular}{lll}
\hline Standard & Sec. & Requirement \\
\hline 6.4 & $\begin{array}{l}\text { 6.4.1 LVRT requirements } \\
\text { Same as GB/T 19963, refer to Figure 2. }\end{array}$ \\
& $\begin{array}{l}\text { 6.4.2. When the voltage at the POI drops to } 20 \% \text { of the rated voltage, } \\
\text { WTGs shall ensure continuous operation with no disconnection for } 625 \\
\text { ms. } \\
\text { NB/T 31003- }\end{array}$ \\
$\begin{array}{l}\text { 6.4.3. When the voltage at POI is able to recover to } 90 \% \text { of the rated } \\
\text { voltage within 2s after dropping, the WTGs shall ensure continuous } \\
\text { operation with no disconnection. } \\
\text { 6.4.4. For WTGs not cut off during the fault period of the power system, } \\
\text { the active power shall rapidly recover after the fault clearance, and it shall } \\
\text { recover to the prefault status with a power change rate of at least } 10 \% \text { of } \\
\text { rated power per second after the fault clearance. }\end{array}$ \\
\hline
\end{tabular}

\subsubsection{U.S. Standards}

FERC Order No. 661 requires WPPs to have LVRT capability down to $15 \%$ of the rated line voltage for 0.625 second. The plant must also be able to operate continuously at $90 \%$ of the rated line voltage, measured at the high-voltage side of the WPP's substation transformer(s) [12]. FERC Order No. 661A amended the LVRT standard, requiring WPPs (following the transient period) to "ride through low-voltage events down to a zero voltage level for 'location specific' clearing times up to a maximum of nine cycles" [13]. ERCOT and ISO-NE also require WTGs to remain interconnected through low-voltage fault conditions of at least nine cycles at $0 \mathrm{~V}$.

Table 33. LVRT Capability: U.S. Standards

\begin{tabular}{|c|c|c|}
\hline Standard & Sec. & Requirement \\
\hline \multirow[t]{4}{*}{$\begin{array}{l}\text { FERC } \\
\text { Order No. } \\
661\end{array}$} & \multirow[t]{4}{*}{ A.i. } & $\begin{array}{l}\text { The standard applies to voltage measured at the POI. Figure } 3 \text { shows the } \\
\text { ratio of actual to nominal voltage (on the vertical axis) over time (on the } \\
\text { horizontal axis). Before time } 0.0 \text {, the voltage at the transformer is the } \\
\text { nominal voltage. At time } 0.0 \text {, the voltage drops. If the voltage remains at a } \\
\text { level that is higher than } 15 \% \text { of the nominal voltage for a period that does } \\
\text { not exceed } 0.625 \text { second, the WPP must stay online. Further, if the voltage } \\
\text { returns to } 90 \% \text { of the nominal voltage within } 3 \text { seconds of the beginning of } \\
\text { the voltage drop (and the voltage at any given time never falls below the } \\
\text { minimum voltage indicated by the solid line in Figure } 1 \text { ), the plant must stay } \\
\text { online. The LVRT equipment must not be disabled while the WPP is in } \\
\text { operation. }\end{array}$ \\
\hline & & Two key features of this regulation are: \\
\hline & & $\begin{array}{l}\text { 1. A WPP must have LVRT capability down to } 15 \% \text { of the rated line } \\
\text { voltage for } 0.625 \text { second. }\end{array}$ \\
\hline & & $\begin{array}{l}\text { 2. A WPP must be able to operate continuously at } 90 \% \text { of the rated } \\
\text { line voltage, measured at the high-voltage side of the WPP } \\
\text { substation transformer(s). }\end{array}$ \\
\hline
\end{tabular}


Standard Sec. Requirement



Figure 3. LVRT requirements in the United States (FERC Order No. 661)

1. WPPs are required to remain in service during three-phase faults with normal clearing (which is a time period of approximately four to nine cycles), single-line-to-ground faults with delayed clearing, and subsequent post-fault voltage recovery to prefault voltage unless clearing the fault effectively disconnects the generator from the system. The clearing time requirement for a three-phase fault will be specific to the WPP substation location, as determined by and documented by the transmission provider. The maximum clearing time the WPP shall be required to withstand a three-phase fault shall be nine cycles at a voltage as low as 0.15 p.u., as measured at the high-voltage side of the WPP step-up transformer (i.e., the transformer that steps the voltage up to the transmission interconnection voltage or "generator step-up transformer"), after which, if the fault remains following the location-specific normal clearing time for three-phase faults, the WPP may disconnect from the transmission system.

FERC

Order No.

$661 \mathrm{~A}$

2. This requirement does not apply to faults that would occur between the WTG terminals and the high-voltage side of the generator stepup transformer or to faults that would result in a voltage lower than 0.15 per unit on the high side of the generator step-up transformer serving the facility.

3. WPPs may be tripped after the fault period if this action is intended as part of a special protection system.

4. WPPs may meet the LVRT requirements of this standard by the performance of the generators or by installing additional equipment (e.g., static VAR compensator) within the WPP or by a combination of generator performance and additional equipment.

5. Existing individual generator units that are or have been interconnected to the network at the same location at the effective date of the Appendix G of the LVRT standard are exempt from meeting the Appendix G LVRT standard for the remaining life of the existing generation equipment. Existing individual generator units that are replaced are required to meet the Appendix G LVRT standard. 


\begin{tabular}{|c|c|c|}
\hline \multirow[t]{2}{*}{ Standard } & \multirow[t]{2}{*}{ Sec. } & Requirement \\
\hline & & Post-transition period LVRT standard \\
\hline & & $\begin{array}{l}\text { 1. WPPs are required to remain in service during three-phase faults } \\
\text { with normal clearing (which is a time period of approximately four to } \\
\text { nine cycles), single-line-to-ground faults with delayed clearing, and } \\
\text { subsequent post-fault voltage recovery to prefault voltage unless } \\
\text { clearing the fault effectively disconnects the generator from the } \\
\text { system. The clearing time requirement for a three-phase fault will } \\
\text { be specific to the WPP substation location, as determined by and } \\
\text { documented by the transmission provider. The maximum clearing } \\
\text { time that the WPP shall be required to withstand a three-phase } \\
\text { fault shall be nine cycles, after which, if the fault remains following } \\
\text { the location-specific normal clearing time for three-phase faults, the } \\
\text { WPP may disconnect from the transmission system. A WPP shall } \\
\text { remain interconnected during such a fault on the transmission } \\
\text { system for a voltage level as low as } 0 \mathrm{~V} \text {, as measured at the high- } \\
\text { voltage side of the wind generator step-up transformer. }\end{array}$ \\
\hline & & $\begin{array}{l}\text { 2. This requirement does not apply to faults that would occur between } \\
\text { the WTG terminals and the high-voltage side of the generator step- } \\
\text { up transformer. }\end{array}$ \\
\hline & & $\begin{array}{l}\text { 3. WPPs may be tripped after the fault period if this action is intended } \\
\text { as part of a special protection system. }\end{array}$ \\
\hline & & $\begin{array}{l}\text { 4. WPPs may meet the LVRT requirements of this standard by the } \\
\text { performance of the generators or by installing additional equipment } \\
\text { (e.g., static VAR compensator) within the WPP or by a combination } \\
\text { of generator performance and additional equipment. }\end{array}$ \\
\hline & & $\begin{array}{l}\text { 5. Existing individual generator units that are or have been } \\
\text { interconnected to the network at the same location at the effective } \\
\text { date of the Appendix G LVRT standards are exempt from meeting } \\
\text { the Appendix G LVRT standard for the remaining life of the existing } \\
\text { generation equipment. Existing individual generator units that are } \\
\text { replaced are required to meet the Appendix G LVRT standard. }\end{array}$ \\
\hline NERC & $\begin{array}{l}\text { PRC-024- } \\
1\end{array}$ & $\begin{array}{l}\text { The requirements specify } 0.0 \text { p.u. fault ride-through for up to nine cycles } \\
\text { with undervoltage durations up to } 3 \text { seconds. The requirements specify } \\
1.20 \text { p.u. fault ride-through for up to nine cycles with undervoltage durations } \\
\text { up to } 1 \text { second. Cumulative voltage duration-based specification is not } \\
\text { specified as an envelope. }\end{array}$ \\
\hline
\end{tabular}




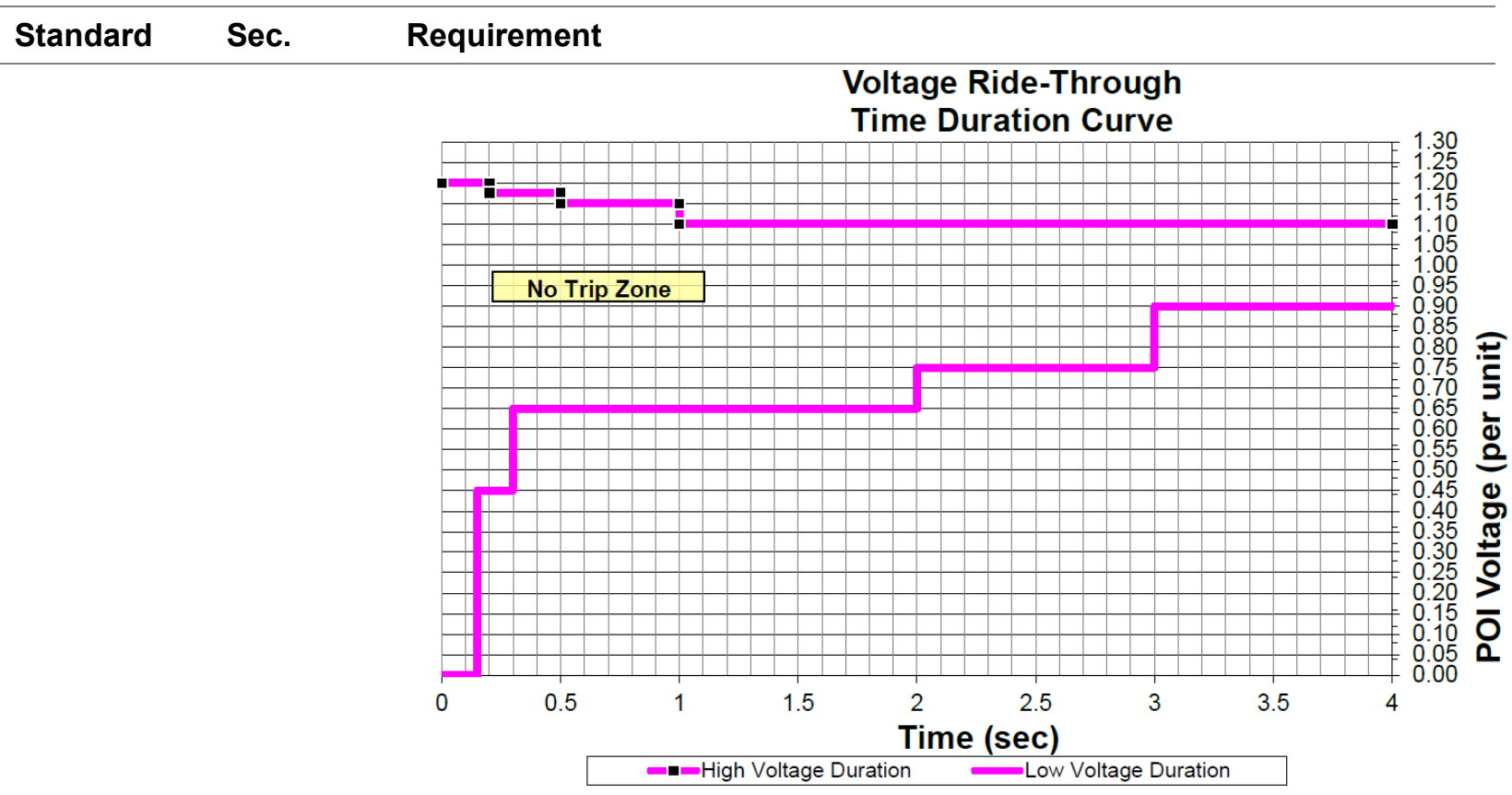

Figure 4. Voltage ride-through time duration curve (NERC PRC-024-1)

WTGs are required to set their relays to remain interconnected through lowvoltage fault conditions of at least nine cycles at $0 \mathrm{~V}$.

Each intermittent renewable resource is required to set generator voltage relays to remain in service for at least 0.15 second during all transmission faults and to allow the system to recover, as illustrated in Figure 5.

Recovery time to $90 \%$ of p.u. voltage should be within 1.75 seconds. Faults on individual phases with delayed clearing (Zone 2) may result in phase voltages outside this boundary, but if the phase voltages remain inside this boundary, then generator voltage relays are required to be set to remain connected and recover, as illustrated.

Each intermittent renewable resource shall remain interconnected during three-phase faults on the ERCOT system for a voltage level as low as $0 \mathrm{~V}$ with a duration of 0.15 second as measured at the POI, unless a shorter

ERCOT

Nodal

Operating

2.9.1

Guides clearing time requirement for a three-phase fault specific to the generating plant POI is determined by and documented by the transmission service provider in conjunction with the small generator interconnection agreement. The clearing time requirement shall not exceed nine cycles.

Each intermittent renewable resource shall set generator voltage relays to remain interconnected to the ERCOT system during the following highvoltage conditions, as illustrated in Figure 5: any p.u. voltage equal to or higher than 1.175 but less than 1.2 for up to 0.2 second, any p.u. voltage equal to or higher than 1.15 but less than 1.175 p.u. voltage for up to 0.5 second, and any p.u. voltage equal to or higher than 1.1 but less than 1.15 for up to 1.0 second. The indicated voltages are measured at the POI.

An intermittent renewable resource may be tripped off-line after the fault clearing period if this action is part of an approved special protection system.

1. Voltage ride-through requirements may be met by the performance of the generators, by installing additional reactive equipment behind the POI, or by a combination of the two. They may also be met by equipment outside 


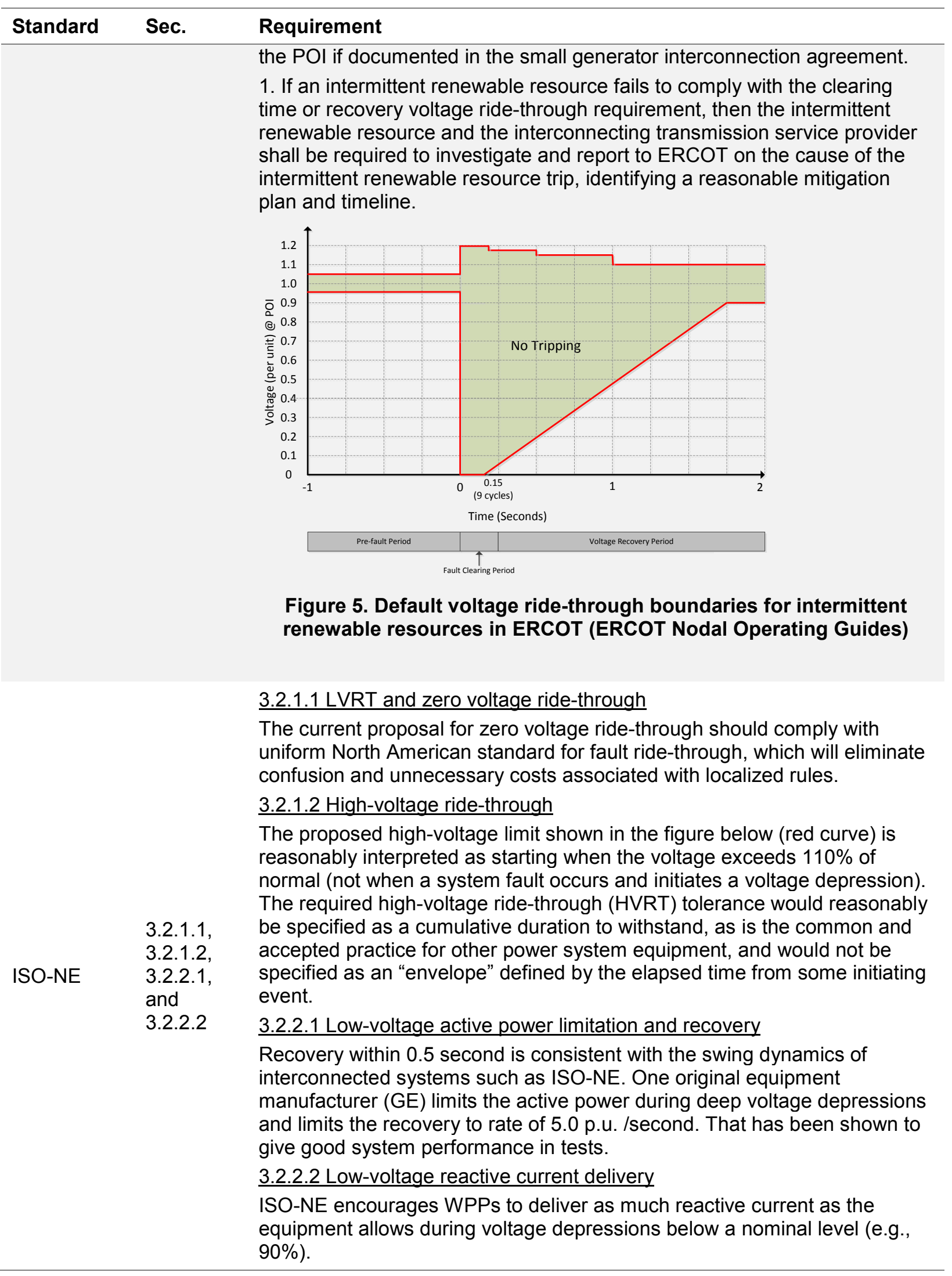




\subsubsection{Summary of the Comparison}

Table 34. Comparative Summary of Standards for Voltage Ride-through Capability

\section{China's Standards}

LVRT

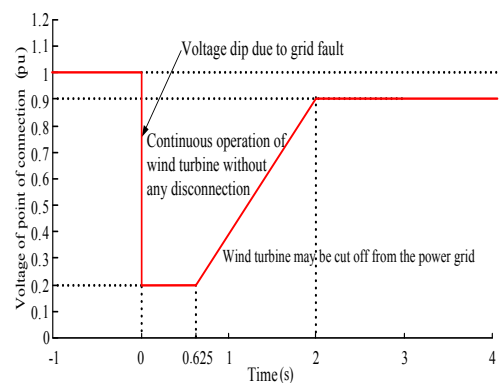

GB/T 19963-2011: Technical rule for connecting a wind power plant to a power system

Recover to the prefault value with a

Active recovery

Dynamic reactive support capacity power change rate of at least $10 \%$ of rated power per second since the fault clearance.

1. Dynamic reactive current control response time shall not be more than $75 \mathrm{~ms}$, and the duration time shall not be less than $550 \mathrm{~ms}$, because the voltage at the point of connection drops.

2. Dynamic reactive current injected to the power system by the WPP $\mathrm{I}_{\mathrm{T}} \geqslant 1.5 \times\left(0.9-\mathrm{U}_{\mathrm{T}}\right) \mathrm{IN}_{\mathrm{N}},\left(0.2 \leqslant \mathrm{U}_{\mathrm{T}} \leqslant\right.$ $0.9)$, where:

- $\mathrm{U}_{\mathrm{T}}=$ per-unit value of voltage at the connection point of the WPP

- $\quad I_{N}=$ rated current of the WPP.
U.S. Standards

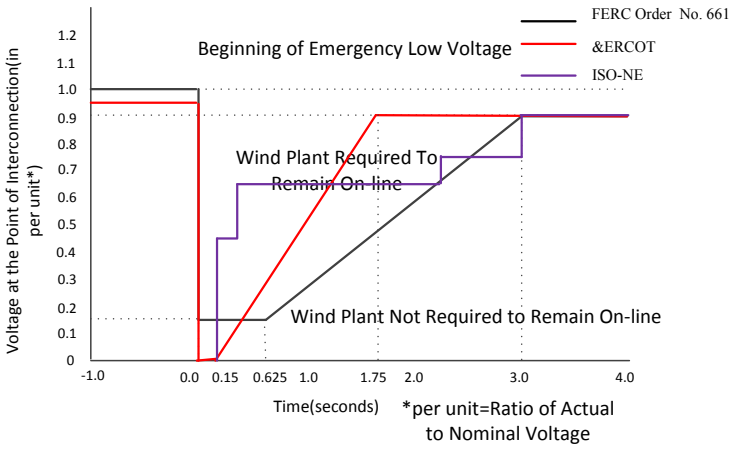

Figure 6. Comparison of LVRT requirements in China to those in the United States

Limiting the recovery to a rate of 5.0 p.u./second has been shown to give good system performance in tests according to ISO-NE.
ISO-NE should encourage WPPs to deliver as much reactive current as is practical with the available equipment during voltage depressions below a nominal level.

\section{HVRT N/A}

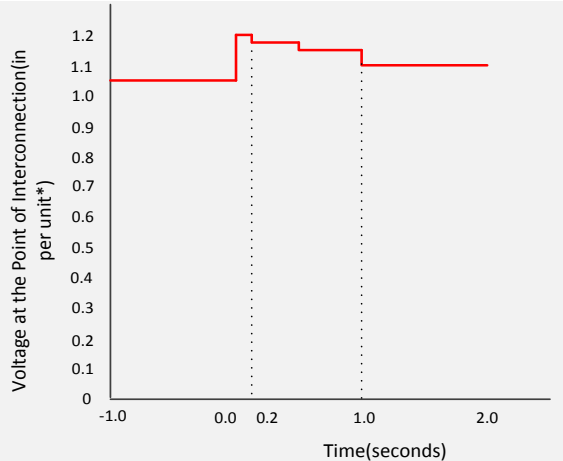

Figure 7. HVRT requirements under NERC 


\subsection{Wind Power Forecasting}

The variability in wind energy production exposes power system operations to risks in electricity supply and cost-effective balancing of load. Wind generation forecasting is an important tool for scheduling wind energy to enhance power system operations [22].

China's standards require WPPs to be equipped with wind power forecasting systems capable of providing 0 -2-hour short-term wind power forecasts and 15-minute-4-hour very short-term wind power forecasts. WPPs should automatically report the forecasting curves of wind power of future 15-minute-4-hour forecasts to the power system dispatch center in 15-minute intervals. WPPs should deliver day-ahead forecasting curves (the time resolution of the predicted values should be 15 minutes) of wind power at a time specified by the power system dispatch center [8].

In the United States, FERC issued Order No. 764 in 2012, requiring (1) public utility transmission providers to offer generation facilities the option to schedule transmission service at 15-minute intervals and (2) operators of renewable generation facilities (20 MW or larger) to provide meteorological and operational data to the transmission providers for more accurate power production forecasting.

ISO-NE recommendations contain a detailed description of the forecasting system of WPPs, including data accessing and forecasting methods. It requires a high degree of reliability and accuracy for aggregate wind generation forecasts. The forecasts are divided into three timescales: (1) very short term ( $0-6$ hours), (2) short-term "day-ahead" (6 hours-72 hours), and (3) medium range ( 3 days-10 days). In addition, a separate ramp forecast is recommended to estimate the provability of a ramp occurring in any given hour [15.] ISO-NE implemented centralized wind forecasting in January 2014 consisting of a 7-day aggregate forecast, 48-hour-ahead forecast, and a 4-hour-ahead forecast.

ERCOT has implemented centralized wind forecasting since 2008. AWS Truepower provides wind forecasts at the individual WPP level and aggregated level for up to the next 48 (rolling) hours, updated hourly and delivered 15 minutes past the hour. Operators of WPPs must then use this forecast when submitting the resource plan or schedule for their WPP [22], [23].

\subsubsection{China's Standards}

Table 35. Wind Power Forecasting: China's Standards

\begin{tabular}{|c|c|c|}
\hline Standard & Sec. & Requirement \\
\hline \multirow{5}{*}{ GB/T 19963} & \multirow{5}{*}{6} & $\underline{6 \text { Wind power forecasting of WPP }}$ \\
\hline & & 6.1 Basic requirements \\
\hline & & $\begin{array}{l}\text { WPPs shall be equipped with wind power forecasting systems that shall } \\
\text { have the functions of } 0-72 \text {-hour short-term wind power forecasting and } \\
15 \text {-minutes-4-hour super short-term wind power forecasting. }\end{array}$ \\
\hline & & 6.2 Forecasting curve report \\
\hline & & $\begin{array}{l}\text { WPPs shall automatically report the forecasting curves of wind power of } \\
\text { future } 4 \text {-hour forecasts to the system dispatch center in } 15 \text { minute- } \\
\text { intervals, and the time resolution of the forecasted values shall be } 15 \\
\text { minutes. }\end{array}$ \\
\hline
\end{tabular}




\begin{tabular}{lll}
\hline Standard & Sec. & Requirement \\
& $\begin{array}{l}\text { WPPs shall daily report the forecasting curves of wind power for the next } \\
\text { day in 0-24 hours at the specified time by the power system dispatch } \\
\text { center, and the time resolution of the predicted values shall be 15 } \\
\text { minutes. }\end{array}$ \\
& $\begin{array}{l}\text { 5.2 Active power of wind forecast } \\
\text { NB/T 31003-2011 } 5.2\end{array}$ & $\begin{array}{l}\text { 5.2.1 The active power of wind should have forecasting abilities } \\
\text { available for 0-72 hours for the short term and 15 minutes-4 hours and } \\
\text { more for short-term wind power predicted values. The time resolutions } \\
\text { for the predicted values are 15-minute increments. }\end{array}$ \\
\hline
\end{tabular}

\subsubsection{U.S. Standards}

Table 36. Wind Power Forecasting: U.S. Standards

\begin{tabular}{|c|c|c|c|c|}
\hline Standard & Sec. & \multicolumn{3}{|l|}{ Requirement } \\
\hline $\begin{array}{l}\text { FERC Order } \\
\text { No. } 661\end{array}$ & & \multicolumn{3}{|l|}{$\mathrm{N} / \mathrm{A}$} \\
\hline $\begin{array}{l}\text { FERC Order } \\
\text { No. } 661 \mathrm{~A}\end{array}$ & & \multicolumn{3}{|l|}{$N / A$} \\
\hline \multirow{3}{*}{$\begin{array}{l}\text { ERCOT Nodal } \\
\text { Operating } \\
\text { Guides }\end{array}$} & \multirow{3}{*}{9.3 .3} & \multicolumn{3}{|c|}{ ERCOT shall prepare monthly reports detailing: } \\
\hline & & \multirow{2}{*}{\multicolumn{3}{|c|}{$\begin{array}{l}\text { 1. Day-ahead forecast wind output, by load zone, by hour for } \\
\text { the operating day, used in the day-ahead reliability unit } \\
\text { commitment and at } 0600 \text { at the day ahead. } \\
\text { 2. Actual wind output, aggregated by load zone, by hour of } \\
\text { the corresponding operating day by load zone. }\end{array}$}} \\
\hline & & & & \\
\hline \multirow{5}{*}{ ISO-NE } & \multirow{5}{*}{4.2} & \multicolumn{3}{|c|}{$\begin{array}{l}\text { ISO-NE should implement a centralized (administered by the } \\
\text { independent system operator) wind power forecasting system. It is } \\
\text { useful to divide the problem into three timescales. The current } \\
\text { centralized wind forecasts (as of September 2015) are summarized } \\
\text { below: }\end{array}$} \\
\hline & & Timescale & Recommendation & $\begin{array}{c}\text { Current Operational } \\
\text { Practice }\end{array}$ \\
\hline & & $\begin{array}{l}\text { Very short } \\
\text { term }\end{array}$ & $0-6$ hours & 7-day aggregate \\
\hline & & Short term & $6-72$ hours & 48-hour-ahead \\
\hline & & $\begin{array}{l}\text { Medium } \\
\text { range }\end{array}$ & $3-10$ days & 4-hour-ahead \\
\hline
\end{tabular}

\subsubsection{Summary of the Comparison}

China's standards require WPPs to be equipped with a wind power forecasting system together with a forecasting curve report. In the United States, the specific requirements for wind power forecasting vary by utility. ISO-NE provides detailed recommendations of the forecasting system of WPPs, including data gathering and forecasting methods. 
Table 37. Summary of the Comparison of the Wind Power Forecasting Standards

\begin{tabular}{llll}
\hline Standard & Medium Range & Short Term & $\begin{array}{l}\text { Very } \\
\text { Short Term }\end{array}$ \\
\hline GB/T 19963 & & 0-72 hours & $\begin{array}{l}\text { Updated every 15 minutes on a 15- } \\
\text { minute interval covering 4 hours }\end{array}$ \\
NB/T 31003-2011 & 0-72 hours & $\begin{array}{l}\text { Updated every 15 minutes on a 15- } \\
\text { minute interval covering 4 hours }\end{array}$ \\
Q/GDW 392-2009 & 0-48 hours & $\begin{array}{l}\text { Updated every 15 minutes on a 15- } \\
\text { minute interval covering 4 hours }\end{array}$ \\
FERC Order No. 764 & $\begin{array}{l}\text { Public utility transmission providers require WPPs provide meteorological and forced } \\
\text { outage data to the transmission utility for subhourly generation forecasting. }\end{array}$ \\
ERCOT & $\begin{array}{l}\text { Day-ahead forecast } \\
\text { updated twice daily }\end{array}$ & $\begin{array}{l}\text { Updated every 15 minutes on a 15- } \\
\text { minute interval covering } 8 \text { hours }\end{array}$ \\
ISO-NE & $\begin{array}{l}\text { 7-day aggregate } \\
\text { wind forecast for } \\
\text { each hour, } \\
\text { updated hourly }\end{array}$ & $\begin{array}{l}\text { 48-hour-ahead wind } \\
\text { forecast that is updated } \\
\text { every 3 hours. }\end{array}$ & $\begin{array}{l}\text { 4-hour-ahead forecast updates } \\
\text { every 5 minutes }\end{array}$ \\
\hline
\end{tabular}

\subsection{Communications Requirements}

China's standards for communications requirements are more specific than those of the United States. China's industry and national standards require WPPs to provide specific communications facilities. In the United States, FERC requires WPPs to have SCADA installed. ISO-NE suggests that the communications of WPPs meet the International Electrotechnical Commission Standard 61400-25 and has protocol requirements for static and real-time operating and weather data transmission.

\subsubsection{China's Standards}

Table 38. Communications Requirements: China's Standards

\begin{tabular}{|c|c|c|}
\hline Standard & Sec. & Requirement \\
\hline \multirow{4}{*}{ GB/T 19963} & \multirow{4}{*}{13.5} & 13.5 Communications of WPPs \\
\hline & & $\begin{array}{l}\text { 13.5.1 WPPs shall be equipped with two route channels, of which at } \\
\text { least one is an optical cable channel. }\end{array}$ \\
\hline & & $\begin{array}{l}\text { 13.5.2 The communications equipment (such as optical fiber } \\
\text { transmission facility, pulse code modulation terminal equipment, } \\
\text { dispatch stored program control exchange, data communications } \\
\text { network, and communications monitoring) of WPPs directly connected } \\
\text { to the power system shall have consistent interfaces and protocol with } \\
\text { the equipment at the connection end of the system. }\end{array}$ \\
\hline & & $\begin{array}{l}\text { 13.5.3 The communications equipment configuration in WPPs shall } \\
\text { be enforced according to the relevant design specifications. }\end{array}$ \\
\hline \multirow{2}{*}{ NB/T 31003-2011 } & \multirow{2}{*}{5.5 .5} & $\begin{array}{l}\text { 5.5.5 The communications of WPPs should be in accordance with the } \\
\text { following requirements: }\end{array}$ \\
\hline & & $\begin{array}{l}\text { 1. The access systems of WPPs should have two routing } \\
\text { channels, of which at least one is an optical cable channel. }\end{array}$ \\
\hline
\end{tabular}




\begin{tabular}{|c|c|c|}
\hline Standard & Sec. & Requirement \\
\hline & & $\begin{array}{l}\text { 2. The communications equipment (such as optical fiber } \\
\text { transmission facility, pulse code modulation terminal } \\
\text { equipment, dispatch stored program control exchange, data } \\
\text { communications network, and communications monitoring) of } \\
\text { WPPs directly connected to the power system shall have } \\
\text { consistent interfaces and protocol with the equipment at the } \\
\text { connection end of the system.3. The communications } \\
\text { equipment configuration of WPPs shall be enforced according } \\
\text { to the relevant design specifications. }\end{array}$ \\
\hline
\end{tabular}

\subsubsection{U.S. Standards}

Table 39. Communications Requirements: U.S. Standards

\begin{tabular}{|c|c|c|}
\hline Standard & Sec. & Requirement \\
\hline $\begin{array}{l}\text { FERC Order } \\
\text { No. } 661\end{array}$ & & $\begin{array}{l}\text { The WPP is required to provide SCADA capability with the specific } \\
\text { SCADA information and control capability required and agreed to by } \\
\text { the WPP and the transmission provider. WPPs are only required to } \\
\text { have the capability to receive instructions; transmission providers } \\
\text { are not authorized to control a WPP in any way. The plant owner } \\
\text { and the transmission provider have the flexibility to negotiate the } \\
\text { specific SCADA capability that meets the needs of the transmission } \\
\text { system at the specific location of the WPP. In addition, the parties } \\
\text { have the flexibility to decide which information should be provided } \\
\text { and which equipment should be installed at the site. }\end{array}$ \\
\hline $\begin{array}{l}\text { FERC Order } \\
\text { No. } 661 \mathrm{~A}\end{array}$ & & $\mathrm{~N} / \mathrm{A}$ \\
\hline \multirow{4}{*}{$\begin{array}{l}\text { ERCOT Nodal } \\
\text { Operating } \\
\text { Guides }\end{array}$} & \multirow{4}{*}{3.15} & $\begin{array}{l}\text { All WTGs must provide a real-time SCADA point that communicates } \\
\text { to ERCOT the number of wind turbines that are available for real } \\
\text { power and/or reactive power injection into the ERCOT transmission } \\
\text { grid. WTGs must also provide two other real-time SCADA points } \\
\text { that communicate to ERCOT the following: }\end{array}$ \\
\hline & & $\begin{array}{l}\text { 1. The number of wind turbines that are not able to } \\
\text { communicate and for which the status is unknown }\end{array}$ \\
\hline & & $\begin{array}{l}\text { 2. The number of wind turbines out of service and not } \\
\text { available for operation. }\end{array}$ \\
\hline & & $\begin{array}{l}\text { WPPs are also required to supply a variety of other telemetry (e.g., } \\
\text { net MW, gross MW, megavolt-ampere reactive, met data) }\end{array}$ \\
\hline \multirow[b]{2}{*}{$\begin{array}{l}\text { ISO-NE } \\
\text { Operating } \\
\text { Procedure }\end{array}$} & \multirow[b]{2}{*}{$\begin{array}{l}\text { OP-14- } \\
\text { Appendix F }\end{array}$} & $\begin{array}{l}\text { The } 2009 \text { recommendations suggest that ISO-NE consider adopting } \\
\text { International Electrotechnical Commission Standard } 61400-25 .{ }^{14}\end{array}$ \\
\hline & & $\begin{array}{l}\text { The operating procedures specify in detail the data requirements } \\
\text { from individual WPPs, including static plant data (e.g., coordinates, } \\
\text { turbine specification, and met gathering stations), as well as real- } \\
\text { time data (e.g., WPP future availability [hourly], plant generation } \\
\text { [every } 4-10 \text { seconds], and curtailment [every } 5 \text { minutes]), which } \\
\text { must be submitted through the ISO's system using the ISO's } \\
\text { protocol. }\end{array}$ \\
\hline
\end{tabular}

${ }^{14}$ Communications for the monitoring and control of wind power plants provides uniform information exchange. 


\subsubsection{Summary of the Comparison}

Table 40. Summary of the Comparison of the Standards for the Communications Requirements

\begin{tabular}{|c|c|c|}
\hline & China's Standards & U.S. Standards \\
\hline \multirow{6}{*}{$\begin{array}{l}\text { Requirements for } \\
\text { communications } \\
\text { equipment }\end{array}$} & GB/T 19963 and NB/T 31003-2011 & \multirow{6}{*}{$\begin{array}{l}\text { FERC: SCADA } \\
\text { ISO-NE: Emergency Management } \\
\text { System }\end{array}$} \\
\hline & $\begin{array}{l}\text { 1. WPPs shall be equipped with two } \\
\text { route channels, of which at least } \\
\text { one is an optical cable channel. }\end{array}$ & \\
\hline & 2. The communications equipment & \\
\hline & power system shall have & \\
\hline & $\begin{array}{l}\text { consistent interfaces and } \\
\text { protocols with the equipment at } \\
\text { the connection end of the system. }\end{array}$ & \\
\hline & $\begin{array}{l}\text { 3. The communications equipment } \\
\text { configuration in WPPs shall be } \\
\text { enforced according to the } \\
\text { relevant design specifications. }\end{array}$ & \\
\hline \multirow[b]{2}{*}{$\begin{array}{l}\text { Requirements for } \\
\text { communications } \\
\text { protocol }\end{array}$} & \multirow[b]{2}{*}{$\begin{array}{l}\text { Q/GDW 392-2009 } \\
\text { The communications mode, transmission } \\
\text { channels, and information transmission } \\
\text { between WPPs and the dispatch center } \\
\text { should be determined by the dispatch } \\
\text { center. }\end{array}$} & ISO-NE: \\
\hline & & $\begin{array}{l}\text { Real-time operational and } \\
\text { meteorological data must be } \\
\text { electronically and automatically } \\
\text { transmitted by the WPP operator to } \\
\text { the ISO over a secure network using } \\
\text { the protocol approved by ISO-NE. }\end{array}$ \\
\hline
\end{tabular}




\section{Summary}

Grid integration of large-scale wind power may impact electric power system quality, voltage, stability, and operations. Standards for grid-connected WPPs provide effective ways to ensure power system security and stability. A comparison of the key technical requirements for gridconnected WPPs in China to those in the United States has been conducted in this report. The report compared China's standards to those of the United States in regards to power quality, power control, voltage control, active power feed-in at overfrequency/underfrequency, frequency range, LVRT capability, HVRT capability, wind power forecasting, and communications requirements. Several key differences are highlighted within each section.

China's standards GB/T and NB/T and U.S. standards under FERC, NERC, ERCOT, and ISO$\mathrm{NE}$ have been included in this study. There are some differences in key technical requirements for grid-connected WPPs, including those for LVRT, HVRT, and voltage control. For instance, in some cases, U.S. standards include more indicators, such as frequency range. In other cases, China's standards are more demanding than those of the United States, such as those for voltage deviation and active power control. Differences between China and the United States in terms of regional wind power penetration, climate, grid infrastructure, and markets are some factors that may contribute to these variations.

Both sets of standards face challenges and are continually changing to become more suitable for their respective grid systems. In China, some of the standards (e.g., GB 18451.1-2001) are directly adopted from U.S. International Electrotechnical Commission standards (61400-1); however, these may not be suitable for local conditions. In addition, climate-specific standardsconcerning typhoons, plateau climates, and low temperatures - have yet to be adopted in China. Further, some standards in both countries need to be updated to the increasing levels of wind in the generation mix.

The characteristics of the generation fleet may change in the near future, with higher percentages of variable generation, modern resource forecasting methods, and advanced computational capabilities that enable power system operators to maintain power system reliability and stability. As wind generation technology progresses, the grid codes must be revised to reflect the technical capabilities and power system conditions. Similarly, regional power system networks and the nature of generation may differ from one place to another; thus, local grid codes must be adhered to ensure regional power system stability and reliability. This comparative study aims to help further the development of relevant technical standards in China and the United States. 


\section{References}

[1] Global Wind Energy Council, Global Wind Report 2014: Annual Market Update (Brussels, Belgium: 2015), http://www.gwec.net/wpcontent/uploads/2015/03/GWEC_Global_Wind_2014_Report_LR.pdf.

[2] “What is U.S. Electricity Generation by Energy Source?" U.S. Energy Information Administration, Frequently Asked Questions, 2015. http://www.eia.gov/tools/faqs/faq.cfm?id=427\&t=3.

[3] “2014 Wind Industry Monitoring Statistics," China National Energy Administration, 2015, http://www.nea.gov.cn/2015-02/12/c_133989991.htm.

[4] Zhongqun $\mathrm{Wu}$, Hongxia Sun, and Yihang Du, "A Large Amount of Idle Capacity Under Rapid Expansion: Policy Analysis on the Dilemma of Wind Power Utilization in China," Renewable and Sustainable Energy Reviews 32 (January 2014): 271-77, doi:10.1016/j.

[5] Rebecca L. Busby, Wind Power: The Industry Grows Up (Tulsa, Oklahoma: PennWell, 2012).

[6] Jidong Wang, Xiaojing Zhang, and Guodong Li Xuhao Du, "Standards of Grid-Connection Technology for Photovoltaic and Wind Power Generations," Electric Power Automation Equipment 31:11 (2011): 1-6.

[7] State Grid Corporation of China, "People's Daily: Integration into the Large Grid Is the Priority," July 16, 2013, http://www.sgcc.com.cn/ywlm/mediacenter/inspotlight/07/295614.shtml.

[8] Beijing General Administration of Quality Supervision Inspection and Quarantine and Standardization Administration of China, Technical Rule for Connecting Wind Farm to Power System: GB/T 19963, 2011.

[9] R. Zavadil, N. Miller, A. Ellis, and Eduardo Muljadi, "Making Connections [Wind Generation Facilities]," IEEE Power and Energy Magazine (November-December 2005).

[10] M.A. Tsili and S. Papathanassiou, "A Review of Grid Code Technical Requirements for Wind Farms," IET Renewable Power Generation 3:3 (2009): 308-32, doi:10.1049/ietrpg.2008.0070.

[11] Müfit Altın, Ömer Göksu, Pedro Rodriguez Remus Teodorescu, and Lars Helle BirgitteBak Jensen, "Overview of Recent Grid Codes for Wind Power Integration," 12th International Conference on Optimization of Electrical and Electronic Equipment (OPTIM) (2010).

[12] U.S. Federal Energy Regulatory Commission, Standard Interconnection Agreement for Wind Energy, Docket No. RM05-4-000, 2005.

[13] U.S. Federal Energy Regulatory Commission, Standard Interconnection Agreement for Wind Energy, Docket No. RM05-4-001, 2005

[14] North American Electric Reliability Corporation, 2012 Special Assessment: Interconnection Requirements for Variable Generation (Washington, D.C.: 2012), http://www.nerc.com/files/2012_IVGTF_Task_1-3.pdf.

[15] GE Energy, Technical Requirements for Wind Generation Interconnection and Integration -New England Wind Integration Study (Schenectady, NY: 2009), http://www.isone.com/committees/comm_wkgrps/prtcpnts_comm/pac/reports/2009/newis_report.pdf.

[16] Warren Lasher, Summary of Significant Wind-Plant Requirements in ERCOT (Washington, D.C.: North American Electric Reliability Corporation, 2010), http://www.nerc.com/comm/PC/Integration\%20of\%20Variable\%20Generation\%20Task\% 
20Force\%20IVGT/Sub\%20Teams/Interconnection/Summary_of_ERCOT_Wind_Plant_Re quirements.pdf

[17] China Electric Power Research Institute, Technical Rule for Connecting Wind Farm to Power System (Recommendations), GB/Z 19963, 2005.

[18] Rao Jianye, X. Xiaodong, and Han Xiaoqi He Zhao, "Comparison on Technical Regulations of China and Other Countries for Grid-Connection of Wind Farms," Power System Technology 36:8 (2012): 44-49.

[19] Beijing State Grid Corporation, Technical Rule for Connecting Wind Farm into Power Grid, Q/GDW 392-2009, 2010.

[20] National Energy Administration, Wind Power Interconnection Technical Regulations, NB/T 31003-2011, 2011.

[21] U.S. Federal Energy Regulatory Commission, Large Generator Interconnection Agreement (LGIA), 2003.

[22] Debra Lew, Michael Milligan, Richard Piwko, and Gary Jordan, "The Value of Wind Power Forecasting" (paper presented at the 91st American Meteorological Society Annual Meeting, the Second Conference on Weather, Climate, and the New Energy Economy, Washington, D.C., January 26, 2011, http://www.nrel.gov/docs/fy1 losti/50814.pdf.

[23] Jennifer Rogers and Kevin Porter, Central Wind Power Forecasting Programs in North America by Regional Transmission Organizations and Electric Utilities: Revised Edition (Technical Report NREL/SR-5500-51263) (Golden, CO: National Renewable Energy Laboratory, 2008-2010), http://www.nrel.gov/docs/fy11osti/51263.pdf. 